\title{
Disharmonization in the Regulation of Transgenic Plants in Europe
}

\author{
By RAMESH BIKRAM KARKY and MARK PERRY
}

\section{EUROPEAN UNION REGULATION ON GENETICALLY MODIFIED PLANTS}

$\mathrm{I}^{\mathrm{N}}$ N the European Union (EU), anti-GMO (genetically modified organisms) groups have a strong presence. The EU market is not favorable to GM products. Retailers are hesitant to sell products with GM labelling. Conventional and organic farmers, environmentalists, and nongovernmental organizations (NGOs) are working to enlarge GM-free zones. Although there are scientific societies arguing for the benefits of biotechnology or GMOs, many major EU member states like Italy, France, and Germany have banned GM maize crop for cultivation.

The EU has 28 member states, ${ }^{1}$ and the legislation issued by the EU has supranational effect on all member states. EU regulations are directly applicable to each member state, and EU directives are to be implemented by member states by incorporation into their domestic law. The European Commission (the Commission), Council of Ministers, and Parliament are involved in the legislative process, and the European Court of Justice (ECJ) interprets EU treaties and legislation. The courts of member states may refer any EU-related legal issues before the ECJ and it may deliver its opinion. In Europe, genet-

Keywords: biotechnology regulation, European development, genetic modification in crops, jurisdictional variations

Dr. Ramesh Karky is Professor of Law at Conestoga College School of Business, Kitchener, Canada. Professor Mark Perry is Professor of Law at the University of New England, Australia. E-mail for Professor Perry: mperry21@une.edu.au

C) Ramesh B. Karky and Mark Perry, 2019; Published by Mary Ann Liebert, Inc. This Open Access article is distributed under the terms of the Creative Commons License (http://creativecommons.org/licenses/by/4.0), which permits unrestricted use, distribution, and reproduction in any medium, provided the original work is properly cited. ically modified technology is strictly regulated. Neither the U.S. nor Canada have enacted any specific laws pertaining to biotechnology or genetically modified organisms. On the other hand, the European Economic Community (EEC), the predecessor of the EU, had passed Community law on genetically modified technology starting in the early 1990s. The main objectives of EU biotechnology legislation are to protect human health and the environment and to ensure the free movement of genetically modified products in the EU.

In pursuance of the above objectives, the framework of European laws on genetically modified plants includes three important principles: safety, freedom of choice, and case-by-case evaluations. Regarding genetically modified plants, Directive $90 / 220$ on the deliberate release into the environment of $\mathrm{GMOs}^{2}$ was the first regulatory framework governing genetically modified plants in Europe. In 2001, the EU repealed Directive 90/220 and issued Directive 2001/18 on the deliberate release into the environment of GMOs. ${ }^{3}$ Directive 2001/18 covers all major aspects of genetically modified plants. There is a particular emphasis on the authorization procedure, scientific assessment of the risks to human and animal health and environment, experimental release into the environment (field trials), and cultivation or placing on the market. However, the EU has left authority with member states when there is an issue of coexistence between

\footnotetext{
${ }^{1}$ At the time of writing. This may be reduced by one this year, 2019.

${ }^{2}$ Council Directive 90/220/EEC of 23 April 1990 on the Deliberate Release into the Environment of Genetically Modified Organisms, [1990] O.J. (L 117/15).

${ }^{3}$ Directive 2001/18/EC of the European Parliament and of the Council 12 March 2001 on the Deliberate Release into the Environment of Genetically Modified Organisms, [2001] O.J. (L 106/1) [Deliberate Release Directive].
} 
genetically modified crops, conventional crops, and organic crops. In this regard, on July 23, 2003, the Commission adopted a Recommendation (2003/ $556 / \mathrm{EC}$ ) on guidelines for the development of national strategies and best practices to ensure the coexistence of genetically modified crops with conventional and organic farming ("2003 Commission Recommendation"). ${ }^{4}$ On July 13, 2010, the Commission repealed the 2003 guidelines and adopted a new Recommendation (2010/C 200/01) on guidelines for the development of national coexistence measures to avoid the unintended presence of GMOs in conventional and organic crops ("2010 Co-existence Recommendation"). ${ }^{5}$ The 2010 guidelines enable member states to develop national measures for coexistence in line with Directive 2001/18/ EC. In case such measures do not work, member states or regions may declare GM-free zones. So far, $16 \mathrm{EU}$ member states have enacted coexistence laws.

In the EU, nobody can conduct the experimental release of genetically modified plants into the environment without authorization from the competent national authority. Two different authorizations are required, one for field trials and one for marketing. After successful field trials, genetically modified plants require authorization from a competent EU authority (EU Commission) before releasing it onto the market or beginning cultivation. In this process, all EU member states must give their consent. Directive 2001/18/EC requires written authorization before commercial use, cultivation, or importation of genetically modified plants. Authorization and procedures (under this Directive) are different depending on if the GM product is capable of being propagated or if the GM product is processed and therefore not made of living materials. This Directive does not require authorization for the importation of processed products that are not capable of growing (not considered organisms), such as corn starch or rapeseed (canola) oil which are made from genetically modified plants. However, there is an authorization requirement when imported crops are living and have the potential for growth (and thus are considered organisms) such as GM maize kernels or GM rapeseed.

Part B of Directive 2001/18/EC contains provisions that govern the authorization procedure for the field trials. Under this Directive, the applicant ("the notifier") needs to submit an application ("the notification") for authorization to the competent authority of the member state where such experimental release will take place. The notification needs to contain an environmental risk evaluation carried out by the notifier. Then, the competent national authority examines the contents of the application and risk evaluation and if it thinks that the application meets the requirements prescribed by the Directive 2001/18/EC, it delivers a decision and authorizes the field trial.

The authorization procedure for placing onto the market or cultivation is complex and long in duration. Part C of Directive 2001/18/EC governs the authorization procedure for commercialization of genetically modified plants. As GM products may go all over the EU, the authorization procedure involves all EU member states. To obtain an authorization for commercialization, an application is required (notification). The application must contain a full environmental risks evaluation and be presented to the competent national authority of the member state where the product will first be marketed or cultivated. After its evaluation, the competent national authority issues an assessment report. If the assessment report is not favorable to the applicant, the applicant may submit a new notification to the competent national authority of another member state. The competent national authority of this member state may issue a different assessment report if the assessment report is in favor of the applicant. That member state informs other EU member states of its opinion through the European Commission. The Commission and the Member States Working Group examine the assessment report and if the report is not objectionable, the competent national authority authorizes the cultivation or placing on the market. Such authorization shall be for a period of ten years, and it may be renewed again if it meets all requirements. If the report is objectionable, the Member States Working Group, Commission, and the notifier enter into a conciliation phase and try to resolve outstanding issues. If objections are maintained, the authorization decision shall take place at the European level.

During the authorization process at the European level, the Commission asks the opinion of the European Food Safety Authority (EFSA). The EFSA is composed of highly qualified scientists and published a guidance document on the environmental

${ }^{4}$ Commission Recommendation 2003/556/EC of 23 July 2003 on Guidelines for the Development of National Strategies and Best Practices to Endure the Coexistence of Genetically Modified Crops with Conventional and Organic Farming, [2003] O.J. (L 189/36) [2003 Commission Recommendation].

${ }^{5}$ Commission Recommendation 2010/C 200/01 of 13 July 2010 on Guidelines for the Development of National Coexistence Measures to Avoid the Unintended Presence of GMOs in Conventional and Organic Crops, [2010] O.J. (C200/1) [2010 Coexistence Recommendation]. 
risks assessment of GM plants in 2010. The EFSA conducts a risk assessment and submits its opinion to the Commission. During this time, the Commission also asks for public opinion and collects comments from the public. The Commission prepares a draft decision and asks for an opinion from its Regulatory Committee which is composed of representatives of the member states. If the Regulatory Committee is in favor of the authorization by qualified majority, the Commission's draft decision will be adopted, published in an official journal, and will also be included in the GMO register. If the Regulatory Committee is against the draft decision by qualified majority, then the Commission informs the European Parliament and submits the draft decision to the European Council of Ministers. If the Council is in favor or the Council is not able to present an opinion within three months, the Commission's draft decision will be adopted. In a situation where the Council gives an opinion against the draft decision by a qualified majority, the draft decision will go back to the Commission to redraft.

After authorization for commercialization, genetically modified plants can be cultivated or brought for marketing. However, EU member states may temporarily ban the cultivation of authorized genetically modified plants in their jurisdiction. An EU member state may ban the cultivation of genetically modified plants or products in two ways. They may invoke the "safeguard clause" under Directive 2001/18/EC or they may declare GM-free zones under coexistence law. Time and again EU member states have invoked the safeguard clause and banned the cultivation of genetically modified plants. There are currently such bans in place in EU member states such as Italy, France, and Germany. Even the ECJ and domestic courts of a few member states have supported and justified the invocation of a safeguard clause.

EU member states' ability to invoke safeguard provisions under Directive 2001/18/EC and to declare a GM-free zone under co-existence law is controversial. The EU has no plans for EU-wide legislation on the coexistence of genetically modified, conventional, and organic crops. The EU Commission considers member states to be in a better position than the EU to identify effective and efficient coexistence measures. On July 5, 2011, the European Parliament voted in favor of a proposal that would make it possible for member states to ban the cultivation of GM crops. To date, Germany, Denmark, France, Portugal, the Netherlands, Belgium, Austria, and some Eastern European countries have legislated on coexistence. Other countries have sub- mitted draft proposals or are still working on proposals. Some member states are not planning to develop coexistence legislation in the near future because they believe that it is highly unlikely that GM crops will be cultivated in their country. Coexistence measures can vary considerably from one country to another. These differences are due to regional differences in agriculture, such as field size or climate. Six member states (Germany, the Czech Republic, Ireland, the Netherlands, Portugal, and Slovakia) have applied more stringent measures to the segregation of GM fields and organic fields than to the segregation of GM fields and conventional fields. Some member states prescribe special measures for the cultivation of GM crops close to nature reserves or prohibit the cultivation of GM crops in these areas altogether. Since these special regulations are not linked to the concept of coexistence, in the view of the Commission, the legal position still remains unclear. $^{6}$

In 2015, the European Union enacted new law. Directive (EU) 2015/412 - on allowing EU countries to restrict or prohibit the cultivation of genetically modified organisms in their territory - amends the 2001 EU Directive so that individual EU countries can ban or restrict GMO cultivation in their territory. ${ }^{7}$ Commission Directive (EU) 2018/350 of March 8, 2018, amending Directive 2001/18/EC of the European Parliament and of the Council as regards the environmental risk assessment of genetically modified organisms, ${ }^{8}$ obligates EU countries to bring into force the laws, regulations, and administrative provisions necessary to comply with this Directive by September 29, 2019, at the latest. Commission Implementing Decision (EU) 2018/1790 of November 16, 2018, repealing Decision 2002/623/ EC establishing guidance notes on the environmental risk assessment of genetically modified organisms (notified under document C [2018] 7513) (text with EEA relevance), ${ }^{9}$ repeals the guidance notes of 2002, which have become obsolete. The repeal

${ }^{6}$ GMO Safety: Genetic Engineering, Plants, Environment, Coexistence Measures to Remain the Responsibility of Member States, GMO SAFETY (June 15, 2009), https:// web.archive.org/web/20100816040652/http://www.gmosafety.eu/coexistence/623.coexistence-measures-remainresponsibility-member-states.html

${ }^{7}$ Directive (EU) 2015/412 of the the European Parliament and of the Council of 11 March 2015, O.J. L 68, 13.3.2015, p. 1-8, available at http://data.europa.eu/eli/dir/ 2015/412/oj (accessed on Dec. 28, 2018).

${ }^{8}$ C/2018/1371; O.J. L 67, 9.3.2018, p. 30-45.

${ }^{9}$ C/2018/7513; O.J. L 293, 20.11.2018, p. 32-33. 
reduces the number of guidance documents that operators and competent authorities need to take into account when carrying out an environmental risk assessment under Annex II to Directive 2001/18/EC.

GM plants authorized for cultivation are subject to labelling and traceability as well. Only plants or products consisting of or containing GMOs (more than 0.9 percent GMO) are subject to the labelling requirements. The labelling requirements are governed by Regulation 1829/2003 on GM food and feed ("Food and Feed Regulation"), ${ }^{10}$ and Regulation $1830 / 2003$ on the traceability and labelling of GMOs and the traceability of food and feed products produced from GMOs. ${ }^{11}$ Likewise, GM plants or products, and plants or products with more than 0.9 percent GMO content, that are authorized for commercialization are subject to traceability requirements. The traceability requirement is governed by Regulation 1830/2003 on the traceability and labelling of GMOs and the traceability of food and feed products produced from GMOs.

There are only a few exemptions to the labelling and traceability requirements mentioned above. There are no such requirements on products such as milk, eggs, or meat obtained from animals fed with GM feed. Conventional or organic plants or products contaminated by GM plants or products below 0.9 percent are also not subject to labelling and traceability provided that such presence of GMO is adventitious or technically unavoidable. There is no threshold for adventitious presence (AP) of GMOs in seeds and there is therefore zero tolerance for GMO content in conventional or organic seeds. Any authorized (for cultivation) conventional or organic seed lots containing GMOs have to be labelled. A seed lot containing GM seed not authorized for cultivation cannot be marketed in the EU.

The EU legal regime and practices regarding genetically modified plants and products are not without criticism. The critics have said that the EU has been protecting its market (agricultural products) from foreign GM agricultural products. This issue was raised before the World Trade Organization (WTO) Dispute Settlement Body in EC-Approval and Marketing of Biotech Products ("ECBiotech"). ${ }^{12}$ In June 1999, the EU had imposed a moratorium on the approval of additional transgenic crops in Europe. In August 2003, the United States, Canada, and Argentina brought a case against the EU before the WTO Dispute Settlement Body claiming that the EU had failed to grant final approval on the marketing of a number of GM crops. It was also claimed that the imposition of national import and marketing bans of GM crops by individual EU member states were not in compliance with the provisions of the WTO agreement. In September 2006, the WTO Panel found that the European Communities applied a general de facto moratorium on the approval of biotech products between June 1999 and August 2003. It had acted inconsistently with its obligations under Annex C(1)(a), first clause, and Article 8 of the Agreement on the Application of Sanitary and Phytosanitary Measures (SPS Agreement) in respect of the approval procedures, and there were undue delays in the completion of the approval procedures. However, the WTO Dispute Settlement Body neither examined the EU regulatory framework on its merit nor said anything on genetically modified organisms and their effect on health and environment.

Any foreign GM plants or products intended for sale or cultivation in the EU market need to fulfil all GMO-related requirements prescribed by EU regulations and directives. There is an assumption that the legal basis for a national cultivation ban will bring a new trade dispute before the WTO Dispute Settlement Body.

In 2016, the French government asked the European Court of Justice (ECJ) to interpret the provisions of the 2001 EU Directive and decide whether the 2001 EU Directive regulates the new gene-editing technology, such as CRISPR-Case9, or not. On July 25, 2018, the ECJ in Case C-528/ 16 decided that organisms including the geneediting technology obtained by mutagenesis are GMOs and are, in principle, subject to the obligations laid down by the GMO Directive. ${ }^{13}$ Other nations, such as the USA and Australia, have taken a different approach to organisms so created by either accepting them as non-GMO or "taking the

\footnotetext{
${ }^{10}$ Regulation (EC) 1829/2003 of the European Parliament and of the Council on Genetically Modified Food and Feed of 22 September 2003, [2003] O.J. (L 268/1) [Food and Feed Regulation].

${ }^{11}$ Regulation (EC) $1830 / 2003$ of the European Parliament and of the Council of 22 September 2003 Concerning the Traceability and Labelling of Genetically Modified Organisms and the Traceability of Food and Feed Products Produced from Genetically Modified Organisms, [2003] O.J. (L 268/24) [Regulation 1830/2003].

${ }^{12}$ World Trade Organization (WTO), European CommunitiesMeasures Affecting the Approval of Marketing of Biotech Products, WTO Doc WT/DS291/R, WT/DS292/R, WT/ DS293/R (2006) [EC-Biotech].

${ }^{13}$ Court of Justice of the European Union, Press Release No. 111/18 Luxembourg (July 25, 2018), Judgement in Case C$528 / 16$
} 
middle ground" of light-touch regulation. ${ }^{14}$ In this case, the ECJ interpreted that only mutagenesis techniques that have conventionally been used in some applications and have a long safety record are exempted from 2001 EU Directive obligations. The court further stated that organisms made using mutagenesis techniques developed after 2001, including gene editing, are not exempted from the Directive. ${ }^{15}$

Furthermore, the EU played an important role in developing the Cartagena Protocol on Biosafety (Protocol) ${ }^{96}$ and ratified the Protocol. The EU has given effect to the requirements of the Protocol by making Regulation 1946/2003 on transboundary movements of GMOs. ${ }^{17}$

\section{EU MEMBER STATE REGULATIONS}

The related rules and regulations of eight EU member state jurisdictions (France, Germany, Spain, the United Kingdom, Portugal, the Netherlands, Belgium, and Italy) are discussed in the following paragraphs.

\section{France}

The subject of GMOs is controversial in France. The issue has been influencing French society and politics from the beginning of GMOs and the country has been divided on this issue. French farmers do not agree with the coexistence of genetically modified and conventional crops. French movements like the Confédération Paysanne consider coexistence as a form of accepting GMOs. On the other side of the argument, French seed producers and chemical companies are in favor of coexistence. They consider GM plants as the key to the future. French consumers support "freedom of choice" and the labelling and traceability for GMOs. ${ }^{18}$ The government of France banned the cultivation of the maize variety MON810 on February 7, 2008, ${ }^{19}$ and the ban has been maintained despite pressure from the European Commission to reverse the ban.

After an extended trial period, France adopted a new biotechnology law in 2008 which guaranteed farmers "the freedom to produce with or without genetically modified organisms." ${ }^{20}$ The new French law contains general provisions for the coexistence of genetically modified and conventional crops. France enacted the new biotechnology law to incorporate European Union directives on GMOs into their domestic law. The European Union had adopted a Directive on the deliberate release of GMOs into the environment in $2001 .^{21}$ Member states were supposed to incorporate this Directive into their national law before October 17, 2002. France was frequently condemned for not meeting this Community obligation. ${ }^{22}$ France was subjected to action for its failure to incorporate Community GM legislation. ${ }^{23}$ The European Commission referred France to the European Court of Justice for not complying with this obligation and the European Court of Justice in Commission v. France ${ }^{24}$ imposed a $€ 10$ million fine on France for delaying adoption of the GMO Directive. France finally complied with this Community obligation by enacting biotechnology law in 2008. At this juncture, it is relevant to mention that

with regards to coexistence rules and the responsibility regime, Directive 2001/18 is silent.... It is up to the [member] states to set up their own rules of coexistence and responsibility. Ultimately, whilst some provisions contained in the law correspond to required

${ }^{14}$ See brief summary in Smriti Mallapaty, Australian GeneEditing Rules Adopt “Middle Ground," Nature (News), Apr. 23, 2019.

${ }^{15}$ Ewen Callaway, EU Law Deals Blow to CRISPR Crops: Top Court's Ruling Threatens Research on Gene-Edited Plants, 560 Nature Aug. 2, 2018, at 16.

${ }^{16}$ Cartagena Protocol on Biosafety to the Convention on Biological Diversity (Jan. 29, 2000), 39 I.L.M. 1027 [Cartagena Protocol].

${ }^{17}$ Regulation (EC) 1946/2003 of the European Parliament and of the Council of 15 July 2003 on Transboundary Movements of Genetically Modified Organisms, [2003] O.J. (L 287/1).

${ }^{18}$ Nicolas Boring Restrictions on Genetically Modified Organisms: France (2014) https://www.loc.gov/law/help/ restrictions-on-gmos/france.php\#_ftn41

${ }^{19}$ Ministerial Decree of 7 February 2008 Suspending the Cropping of Genetically Modified Maize Seed (Zea Mays L. Line MON810), Journal Officiel de la Republique Francaise (JORF) No. 34 of 9 February 2008, NOR: AGRG0803466A, amended 13 February 2008 NOR: AGRG0803888A.

${ }^{20}$ Law No. 2008-595 of 25 June 2008 Relating to GMOs, JORF No. 148 of 26 June 2008, NOR: DEVX0771876L (codified at Arts. L.531-1 et seq. of the Code de l'Environment).

${ }^{21}$ Deliberate Release Directive, supra note 3.

${ }^{22}$ C-296/01, Commission v. France, [2003] ECR I-13909, and C-429/01, Commission v France, [2003] ECR I-14355. ${ }^{23}$ Luc Bodiguel, Michael Cardwell, Ana Carretero Garcia, and Domenio Viti, Coexistence of Genetically Modified, Conventional, and Organic Crops in the European Union: National Implementation, in The Regulation of GenetiCally Modified Organisms: Comparative Approaches (Luc Bodiguel and Michael Cardwell, eds., London: Oxford University Press, 2010), at 166.

${ }^{24}$ C-121/07, Commission v. France, [2008] ECR I-09159. 
incorporation of the directive, the main points of this law (High Council, rules of coexistence and responsibility) are not a Community obligation. $^{25}$

The new biotechnology law enacted by the French National Assembly and Senate went into effect on June 26, 2008. This new law established the right to produce "with or without GMOs" and it has brought three major changes: the creation of a new mechanism of GMO evaluation in France, the required adoption of "rules of coexistence," and the creation of a special responsibility regime in the case of crop contamination by GMOs. ${ }^{26}$ It guarantees the use of GMOs "with the respect to common prescriptions," indicating that agricultural products with less than $0.9 \%$ genetically modified organisms will be regarded as GMO free. If the threshold of $0.9 \%$ is exceeded, by cross-pollination for example, a neighboring farmer or beekeeper will be entitled to compensation for his or her loss of income. Minimum distances that ensure the coexistence of genetically engineered and conventional or organic cultures will be defined by decree of the Minister of Agriculture. Such distances will be reviewed every other year. The Senate also has introduced a new clause into the draft law that makes the destruction of GMO cultures a punishable offense. Two to three years of imprisonment and a penalty of $€ 75,000$ to $€ 150,000$ may be imposed upon socalled "field liberators." ${ }^{27}$ The French government has issued a decree and set 50 meters as a minimum distance buffer for GM maize cultivation. ${ }^{28}$ The newly created "High Council of Biotechnology" (HCB) is an expert board which deals exclusively with GMOs. The HCB hears all questions pertaining to GMOs and has experts who answer each question. The HCB has two committees: a scientific committee and a social and ethical committee.

Regarding the executing agencies, the Ministry of Agriculture and Fisheries is responsible for authorizing the release of new crops into the environment for commercial use with approval of the Ministry of Ecology, Energy, Sustained and Territory Development. The Ministry of Research is responsible for authorizing the use of GMOs in research and development. GMO appraisals and authorizations are conducted by the HCB when related to the environment and public health. Appraisals and authorizations are conducted by the French Agency for Food Security when related to food sanitation and security (human and animal food). Controls are carried out by the General Directorate for Fair Trading, Consumer Affairs and Fraud Controls (all food and feed products and EU produced seeds), the General Directorate for Food (Ministry of Agriculture and Fisheries, DGAL, imported seeds), and by the Group for the Control and Certification of Seed Varieties (GEVES) for seed certification. ${ }^{29}$

The new biotechnology law creates a notification obligation for farmers who intend to grow GMOs. They must inform neighboring plot owners of their intention. It also contains a provision of liability for any loss of income by cross-pollination: however, there are no insurance policies to cover such risks in France. ${ }^{30}$ Regarding public participation, Article 24 of the new law has an identical provision to the Aarhus Convention provision that states, "The State ensures, at an early stage, public information and participation, before making decisions related to GMO cultivation and its marketing." 31 There is nothing in the law which specifies how this obligation will be met. ${ }^{32}$ The courts have already declared Internet consultation with the public on the trials insufficient. ${ }^{33}$

The new biotechnology law sets rules concerning the different varieties of GMO plants authorized in France, but at the same time, it does not define "GMO-free." 34 It further requires decree and

\footnotetext{
${ }^{25}$ Anne Furet (brochure coordinator), Citizen Watch Group for Information Relating to GMOs, The French Law on GMOs: "Balanced" or Biased?, Inf'OGM (France) (July 2008), http://infogm.org, at 3.

${ }^{26} I d$. at 1.

${ }^{27}$ France struggles with its attitude towards biotechnology https://web.archive.org/web/20100116050842/http://www .coextra.eu/country_reports/news1153_en.html (visited Nov. 29, 2011).

${ }^{28}$ Genetically Modified Organisms in France https://french foodintheus.org/1028

${ }^{29}$ supra note 18 .

${ }^{30}$ supra note 18.

${ }^{31}$ Aarhus Convention on Access to Information, Public Participation in Decision-Making and Access to Justice in Environmental Matters, 1998, concluded under the auspices of the United Nations Economic Commission for Europe. The European Community ratified the Convention in 2005. See Council Decision (EC) 2005/370 of 17 February 2007 on the Conclusion, on Behalf of the European Community, of the Convention on Access to Information, Public Participation in Decision-Making and Access to Justice in Environmental Matters [2005] O.J. (L 124/1); and see also Regulation (EC) $1367 / 2006$ of the European Parliament and of the Council on the Application of the Aarhus Convention on Access to Information, Public Participation in Decision-Making and Access to Justice in Environmental Matters to Community Institutions and Bodies [2006] O.J. (L 264/13).

${ }^{32}$ Furet, supra note 25, at 13.

${ }^{33}$ Id.

${ }^{34}$ Ouisse, Coexistence Measures, supra note 30.
} 
bylaw notice regarding the final definition of "GMO-free" products and technical conditions of coexistence. ${ }^{35}$ In this context, "two decrees have been published regarding the High Council of biotechnologies and committee of national biological surveillance functioning. ... A third decree concerning labelling of GMO for the use of a third party within a confined use only has been published in January 2009." "36 "In the absence of decrees specifying how the law should be enforced, it is difficult to draw up a complete summary of the implications of this text, and important notions remain to be defined (e.g., 'GMO-free,' the functioning of the High Council, the rules of coexistence, responsibility, seed labelling)."37

In Europe, the future of transgenic plants has not been decided. ${ }^{38}$ France lacks regulation in the area of seeds because the EU also lacks regulations on seeds in terms of biotech traceability, labelling, and thresholds. Article 21 of the new law allows the French administration to set thresholds under which seeds containing GMOs will have to be labelled. Regarding the Cartagena Bio-Safety Proto$\mathrm{col},{ }^{39}$ France is in line with the EU.

In France, the majority of consumers are not in favor of GMOs. Agricultural biotechnology has been facing market acceptance issues, and GMOlabelled food products are generally not available. ${ }^{40}$ "The Ministry of Agriculture plans to issue more concrete, crop-specific cultivation rules, such as minimum separation distances. It also plans to continue the production and marketing of products with the special designation 'GMO-free." The Ministry ensures that restrictions will be implemented on cultivation of GM varieties where regional products with quality signs, such as AOC certification (the French "certified origin" label) are grown and a cultivation prohibition in national and regional parks. ${ }^{41}$ In France, several anti-GMO groups have destroyed transgenic corn plantations and there is also a call for the discontinuation of civil disobedience. In response to the demands of anti-GMO movements, several local authorities banned GMO field trials and commercial use. The French Administrative Court has cancelled most of those bylaws.

In France, domestic courts have always favored GM cultivation. An organic beekeeper whose hives were situated near GM maize-cultivated land filed a lawsuit for cross-pollination before a court. In 2007, the court turned downed the application of the beekeeper on the ground that the GM crop concerned was properly authorized and the production was lawful. ${ }^{42}$ In another case, Land Oberosterreich v. Commission, ${ }^{43}$ a local authority banned GMOs within its territory, but a French court found no legitimacy to
"GM-free" zones in Community law. French law also, except in the case of national parks or regional natural parks, does not allow local bans on GMO cultivation. The French administrative judges also annulled many municipal decisions to declare "GMfree" zones and to ban GMO cultivation. ${ }^{44}$ Since the enactment of the biotechnology law in France, change can be seen in judicial direction. On December 5, 2008, the Administrative Tribunal of Nimes did not annul the ban imposed by the Municipal Council of the Commune of Le Thor. ${ }^{45}$

In Europe, the campaign following the "Charter of Florence" promotes GM-free agriculture. In France, regions like Aquitaine, Bretagne, Île de France, Limousin, and Poitou-Charente are members of the Charter. However, the European Commission has decided that regional governments have no competency to ban GMOs. ${ }^{46}$

The ECJ, in Association Greenpeace Francev. Ministere de l'Agriculture et de la Peche ${ }^{47}$ examined whether a member state (France), having transmitted a favorable opinion to the European Commission during the authorization procedure for placing a GMO on the market, was then obliged to issue written consent allowing the product to be placed on the market. In this case, the ECJ ruled that a member state (France) could withhold consent provided that it had received

\footnotetext{
${ }^{35} I d$.

${ }^{36} \mathrm{Id}$.

${ }^{37}$ Furet, supra note 25 , at 15.

${ }^{38} I d$.

${ }^{39}$ Cartagena Protocol, supra note 16.
}

${ }^{40}$ Mark Cantley, "An Overview of Regulatory Tools and Frameworks for Modern Biotechnology: A Focus on Agro-Food" (Paper prepared for the OECD International Futures Project on "The Bioeconomy to 2030: Designing a Policy Agenda," February 2007), Organisation FOR ECONOMic Co-OPERATION AND DeVElopment, http:// www.oecd.org/dataoecd/11/15/40926623.pdf, at 74 .

${ }^{41}$ Ouisse, Coexistence Measures, supra note 30.

${ }^{42}$ CA Agen, Civ 1, 12 July 2007, No. 07/00842.

${ }^{43} \mathrm{~T}-366 / 03$ and T-235/04, Land Oberosterreich v. Commission, [2005] ECR II-4005; and C-439/05P and C-454/05P, Land Oberosterreich v. Commission, [2007] ECR I-7141.

${ }^{44}$ CAA Boardeaux, 22 September 2004, No. 04BX011452, Prefet de la Haute Garonne; CAA de Bordeaux, 15 May 2007, No. 06BX01555, Commune de Londigny; and others. ${ }^{45}$ TA Nimes, 5 December 2008, No. 0802882, Prefet de Vaucluse c/ Commune de le Thor.

${ }^{46}$ Ouisse, Public Debate, supra note 18.

${ }^{47} \mathrm{C}-6 / 99$, Association Greenpeace France and Others v. Ministere de l'Agriculture et de la Peche, [2000] ECR I1651. See also A. Mastromatteo, A Lost Opportunity for European Regulation of Genetically Modified Organisms, 25 European L. Rev. 425 (2000). 
new information indicating a possible risk to human health and the environment.

On September 8, 2011, the ECJ, in Monsanto SAS and Others v. French Minister for Agriculture and Fisheries, ${ }^{48}$ ruled that a French ban on the cultivation of genetically modified crops is procedurally incorrect. In this case, the French government invoked a safeguard clause in Directive 2001/18 on the deliberate release into the environment of GMOs $^{49}$ and banned the cultivation of MON810 maize in 2008. In accordance with the safeguard clause, a member state can ban cultivation of a GMO on its own initiative provided new findings about a potential risk to humans or the environment are present. At the same time, France had maintained experimental crops. Monsanto and a number of seed producers challenged the measures taken by the French administration before the Conseil d'Etat (the highest French administrative court). The Conseil d'Etat referred the case to the ECJ.

A decision on April 22, 1998, by the European Commission authorized MON810 maize to be placed on the market at the request of Monsanto Europe, on the basis that Directive 90/220/EEC on the deliberate release into the environment of GMOs was in force. Pursuant to the European Commission decision, France also authorized MON810 maize to be placed on the market. On May 4, 2007, Monsanto Europe applied for renewal of the authorization to place MON810 maize on the market pursuant to Regulation No. 1829/2003 on genetically modified food and feed. ${ }^{50}$ Monsanto Europe put forward to the Commission that MON810 maize was an existing product and had been lawfully placed on the market.

In this Monsanto case, the ECJ stated that, when a member state is wanting to adopt emergency measures under Regulation No. 178/2002, it must comply not only with the substantive conditions set out in Regulation No. 178/2003, but also with the procedural conditions set out in Regulation No. 178/ $2002 .{ }^{51}$ The ECJ further held: "With a view to the adoption of emergency measures, Article 34 of Regulation No 1829/2003 requires member states to establish, in addition to urgency, the existence of a situation which is likely to constitute a clear and serious risk to human health, animal health or the environment." 52

On November 28, 2011, the Conseil d'Etat ruled that the 2008 French ban on the cultivation of GM crops was illegal. The French Court overturned the French national ban in line with an ECJ judgment declaring that the French government had presented no scientific evidence of any risk to health or the environment from these crops. After this judgment of the ECJ, the Environment Minister of France announced her intention to keep the ban on Monsanto's MON810 maize in France and to invoke the safeguard clause again. ${ }^{53}$

\section{Germany}

In Germany, the Amflora potato, produced primarily for amylopectin starch, is the only genetically modified crop that can be grown commercially. The cultivation of GM maize (MON810) has been provisionally banned in Germany since April 17, 2009. ${ }^{54}$ In Germany, research, production, and consumption of genetically modified plants and products have been controversial for a long period of time. The food chain is reluctant to handle products with biotech labelling. NGOs are working to keep biotech crops off the fields and biotech food products off the shelves. Antibiotech activists have been continuously destroying test plantings. Environmental and consumer-related NGOs and the Green Party are generally hostile toward biotech crops. However, the scientific community and center-right political parties support the use of biotechnology.

Genetic Engineering Act. In Germany, the regulatory framework for biotech products is set by EU regulations and directives. The Gentechnikgesetz (Genetic Engineering Act, also known as Gene Technology Act $)^{56}$ is a special legal regime for GMOs in Germany. It has been amended several times and transposed EU Directive 2001/18/EC on

${ }^{48} \mathrm{C}-58 / 10$ to C-68/10, Monsanto SAS and Others v. French Minister for Agriculture and Fisheries, [2011] ECR I-07763 [Monsanto SAS].

${ }^{49}$ Deliberate Release Directive, supra note 3.

${ }^{50}$ Food and Feed Regulation, supra note 10.

${ }^{51}$ Monsanto SAS, supra note 48, at paras 73 and 74 .

${ }^{52} I d$. at para 82(3).

${ }^{53}$ GMO Safety: Genetic Engineering, Plants, Environment, ECJ: French Ban on MON810 Maize Has No Legal Basis, GMO SAFETY (Sept. 9, 2011), https://web.archive.org/web/ 20140826111345/www.gmo-safety.eu/news/1349.ecj-nationalcultivation-ban-mon-maize-french-no-legal-basis.html

${ }^{54}$ Agra Europe Weekly, No. 2357, 17 April 2009, EP/1. See also C-442/09, Karl Heinz Bablok and Others v. Freistaat Bayern, [2011] I-7419, at para 29 [Bablok].

${ }^{55}$ Cantley, supra note 40 , at 75.

${ }^{56}$ Genetic Engineering Act 1990, Bundesgesetzblatt (BGB1) 1990 I, p. 1080. Major amendments occurred in December 1993 (BGB1. 1993 I, p. 2066), December 2004 (BGB1. 2005 I, p. 186), March 2006 (BGB1. 2006 I, p. 534), and April 2008 (BGB1. 2008 I, p. 499). 
the deliberate release into the environment of GMOs $^{57}$ into domestic law. According to the Genetic Engineering Act,

All genetically modified plants including field trials and commercial cultivation are to be entered into a public register. Notifications must be received three months in advance for commercial cultivation, or three days in advance for a field trial. The entry in the register must specify the name and the unique identifier of the GMO, its novel trait(s), site location and size, and the name and address of the farmer or scientist. Personal information is withheld from the public unless it is of personal interest to an inquirer, e.g., if a farmer wants information on who is growing GM crops in the immediate vicinity. ${ }^{58}$

The German Genetic Engineering Act states that, "farmers growing GM plants are liable for all economic losses incurred on neighbouring farms due to unwanted admixture regardless of whether or not a direct link can be ascertained. An economic loss occurs when a neighbouring farmer's harvest exceeds the 0.9 percent threshold for GM content that makes it illegal to sell the harvest without a GMO label." 59 The law furthers farmers' liability stating,

Farmers growing GM crops are still liable even if they followed the codes of good agricultural practice designed to prevent outcrossing and admixing.... Farmers growing GM crops should be vigilant of volunteers the following year and take care to avoid mixing of GM and non-GM goods during storage and transport. Workers that deal with GM plants are required to have suitable training, and seed companies are asked to provide cultivation and handling recommendations to farmers. ${ }^{60}$

Directives on best-practice procedures have been in place in Germany since 2008 for the cultivation of GM plants, particularly for GM maize. According to these directives, which are binding, a minimum distance of 150 meters is to be kept between fields of GM and conventional maize, and a distance of 300 meters for organic maize. "61 "The system for testing and controlling the illegal entry of biotech products is decentralized to the 16 German Länder, who establish their own monitoring and sampling plans. Sampling is primarily done at the wholesale and the processing level." ${ }^{62}$
Agencies. The Federal Ministry for Food, Agriculture, and Consumer Protection (BMELV) is the leading agency for biotechnology policy in Germany. In addition, the Ministries of Economics, Health, Research, and Environment also provide input and are involved in the decision-making process. These agencies also need to approve Germany's voting positions in EU committees and councils. This responsibility applies to the Biosafety and Biodiversity committees as well. The regulatory office for biotech authorization and risk assessment is under the political leadership and supervision of BMELV, which has positive views on biotechnology. ${ }^{63}$

Case law. German courts have already examined the constitutionality of the Genetic Engineering Act, and they have also interpreted major provisions of the Act. The European Court of Justice has also added meaningful interpretation.

In 2005, the German Federal State of SaxonyAnhalt brought a legal action against the Genetic Engineering Act before the Federal Constitutional Court of Germany. The Federal Constitutional Court of Germany dismissed the action and upheld the restrictive provisions for the cultivation of genetically modified plants and liability on November 24, $2010 .^{64}$ In their legal reasoning, the judges stated,

The legislature has a particular duty of care in view of the fact that the state of scientific knowledge has not yet been finally established when assessing the long-term consequences of the use of genetic engineering. In making law,

\footnotetext{
${ }^{57}$ Deliberate Release Directive, supra note 3, as amended by Food and Feed Regulation, supra note 10, at page 24.

${ }^{58}$ GMO Compass: Country Reports, Coexistence in Germany, GMO Compass (July 2, 2016), https://web.archive.org/web/ 20160702063612/http:/www.gmo-compass.org/eng/news/ country_reports/236.coexistence_germany.html ${ }^{59} I d$.

${ }^{60}$ Id.

${ }^{61}$ Farming Regulations: German Constitutional Court Confirms Biotech Law, GMO CoMPass (Nov. 15, 2016), https://web.archive.org/web/20161115054354/http:/www.gmocompass.org/eng/news/546.docu.html

${ }_{62}^{62}$ Cantley, supra note 40 , at 76.

${ }^{63} \mathrm{Id}$.

${ }^{64}$ BVerfG, Judgment of the First Senate of 24 November 2010, $1 \mathrm{BvF} 2 / 05$, paras. (1-316), http://www.bundesverfassungs gericht.de/entscheidungen/fs20101124_1bvf000205.html; http://www.bundesverfassungsgericht.de/en/press/bvg10108en.html. See also Federal Constitutional Court, Press Release No. 108/2010 of 24 November 2010, Judgment of 24 November 2010, 1 BvF 2/05.
} 
it must not only balance the constitutionally protected interests affected by the use of genetic engineering on the one hand and their regulation on the other hand, but must similarly comply with the duty contained in Article 20a GG to also protect natural resources with responsibility for future generations. ${ }^{65}$

In this case, "Saxony-Anhalt had raised particular issue with the regulations on legal responsibility and on the keeping of a site register, claiming that these inappropriately hinder the cultivation of GM plants. According to the suit, such regulations are compatible neither with the freedom of employment ensured by the constitution nor with the guarantee of ownership and the concept of equality before the law." ${ }^{66}$ In this case, "the federal state had argued that the register would provide radical opponents of gene technology with information on the precise whereabouts of fields with GM plants, which then would be vulnerable to acts of destruction." 67

In another case, the German Administrative Court approved the ban on the cultivation of genetically modified maize MON810. On April 14, 2009, the German Minister of Agriculture banned the cultivation of genetically modified Bt. maize MON810 in Germany. Monsanto then went to the Braunschweig Administrative Court to argue against the ban, but Monsanto's urgent appeal was rejected. The court stipulated that the presence of indicators showing risk to the environment is sufficient for a cultivation ban on genetically modified crops or plants. ${ }^{68}$ The court held that "[u]nder EU law, national cultivation bans relating to genetically modified crops that have been authorised at the EU level are admissible only if there are new scientific findings that would indicate potential risks to the environment." ${ }^{69}$ In the same case, the German Administrative Court stated that

there do not need to be confirmed scientific findings available in order for a temporary cultivation ban to be valid. All that was needed was for there to be new or additional indications that humans or animals might be at risk. ... The Court cites case-law of the European Court of Justice, which states that a lack of scientific proof of a risk is no reason not to take all steps to prevent the risk occurring. In the event of uncertainties regarding the existence or scale of risks, safety precautions could be taken without waiting for the risks to be fully investigated. ${ }^{70}$

However, the Court's decision was only a preliminary decision. Following this ruling, the Higher
Administrative Court of Lower Saxony in Lüneburg also supported the legality of the decis This case is still pending before the Braunschweig Administrative Court.

In Karl Heinz Bablok and Others v. Freistaat Bayern, C-442/09 $9^{71}$ (known as the "Honey case"), the ECJ passed a judgment related to the German Genetic Engineering Act. The ECJ stated that honey and food supplements containing pollen derived from a GMO are foodstuffs produced from GMOs which cannot be marketed without prior authorization. ${ }^{72}$ The ECJ stated, "Pollen is itself no longer a GMO when it has lost its ability to reproduce and is totally incapable of transferring genetic material." ${ }^{73}$ The ECJ further set out that the Deliberate Release Directive ${ }^{74}$ provides that such organisms may be released deliberately into the environment or placed on the market only when prior authorization has been given. ${ }^{75}$ The ECJ also stipulates that the regulation on genetically modified food ${ }^{76}$ provides that GMOs for food use, foodstuffs containing or consisting of GMOs, or foodstuffs produced from ingredients produced using or containing GMOs must be authorized before being placed on the market. $^{77}$

The Honey case ${ }^{78}$ was referred to the ECJ by the Bavarian Higher Administrative Court of Germany. In 2005, Mr. Bablok, an amateur beekeeper, found MON810 maize DNA and genetically modified proteins in his beehives situated 500 meters from the plots of land belonging to Freistaat Bayern, a GM farmer. Very small amounts of MON810 maize DNA were detected in a number of samples of Mr. Bablok's honey. Mr. Bablok took the view that the

\footnotetext{
${ }^{65}$ Federal Constitutional Court, Press release No. 108/2010 of 24 November 2010, Judgment of 24 November 2010, 1 BvF 2/05.

${ }^{66}$ Farming Regulations, supra note 61.

${ }^{67} \mathrm{Id}$.

${ }^{68}$ GMO Safety: Genetic Engineering, Plants, Environment, Braunschweig Administrative Court Upholds MON810 Ban, GMO SAFETY (May 5, 2009), https://web.archive.org/ web/20140826143125/http://www.gmo-safety.eu/news/613 .braunschweig-administrative-court-upholds-mon810-ban.html ${ }^{69} I d$.

${ }^{70} \mathrm{Id}$.

${ }^{71}$ Bablok case, supra note 54.

${ }^{72} I d$. at para 109.

${ }^{73} I d$. at para 62.

${ }^{74}$ Deliberate Release Directive, supra note 3, as amended by

Food and Feed Regulation, supra note 10, at page 24.

${ }^{75}$ Bablok case, supra note 54, at para 92.

${ }^{76}$ Food and Feed Regulation, supra note 10.

${ }^{77}$ Bablok case, supra note 54, at para 109.

${ }^{78} I d$.
} 
presence of residues of genetically modified maize made his honey unmarketable and not suitable for consumption, and he therefore brought legal proceedings against Freistaat Bayern. Four other amateur beekeepers also joined in this proceeding. In this case, the Bavarian Higher Administrative Court sought clarification and asked the ECJ whether the mere presence of GM maize pollen which has lost its ability to reproduce in the apicultural products in question, has the consequence that those apicultural products may not be placed on the market without authorization.

Before the ECJ judgment in the Honey case, pollen from GM plants in honey was not regulated by food legislation, and it was considered as an adventitious and unavoidable impurity. This situation has been changed now. ${ }^{79}$ Consequently, honey containing pollen from GM plants falls within the scope of the regulation on genetically modified food and feed. ${ }^{80}$ However, as GM plants are not grown commercially in Germany, this case is not expected to have a big impact on honey produced in Germany. But the situation will be different for honey from other European countries such as Spain, where MON810 maize is grown on around 80,000 hectares. $^{81}$ It remains to be seen how this situation will progress. There is the issue of labelling as well. Honey that contains pollen from authorized GM plants has to be labelled as such if the GM pollen from authorized GM plants accounts for more than 0.9 percent of the total pollen content. $^{82}$

In this context, then-German Agriculture Minister Ilse Aigner asked her administration to reassess the current separation distances. Furthermore, Bavarian Environment Minister Markus Söder called for a three-kilometer safety distance between beehives and GM crops fields. Others, like Friends of the Earth Germany (BUND) and the German Society for Nature Conservation (NABU), are calling for a separation distance of at least five kilometers. The president of the German Beekeeping Association (DIB), Peter Maske, is calling for a ten-kilometer separation distance. ${ }^{83}$ As there are no GM crops in Germany, the impact of the ECJ ruling will have less impact. Otherwise, it would be more difficult to conduct field trials for GM crops. ${ }^{84}$

Comments on new law. The German Genetic Engineering Act has also been criticized as hostile to GM farmers. The current version of the Genetic Engineering Act lacks specific, practical measures for coexistence, such as prescribed separation distances. ${ }^{85}$ The Act is restrictive for research, production, and trade. It discourages GM farmers from planting crops. Rules relating to liability and coexistence are not favorable to GM farmers. ${ }^{86}$ Requirements like public registration of GM crops may be used to facilitate civil disobedience and to intimidate GM farmers considering planting GM varieties. ${ }^{87}$ It is also said that,

[a]ccording to these regulations, a farmer who sows GM plants is liable for all economic damage that results in conventional stocks through cross-pollination. This liability is binding even in the case in which the "GMOfarmer" has complied with all directives and therefore bears no fault for the cross-breeding damage. In the case that no individual source of the damage may be identified, all GM-planting farmers of the affected region are collectively responsible. $^{88}$

Amendment to the Genetic Engineering Act. Germany has been debating amending the existing portions of the Genetic Engineering Act. A new amendment may give greater latitude to the regions (federal states) in the determination of internal rules for the cultivation of GM plants. However, concerns have been raised about whether such provisions will be compatible with the ruling of the Constitutional Court. The Constitutional Court affirms that it is the task of the national government to ensure standard regulations nationwide. ${ }^{89}$

Other contradictions. The cultivation of GM maize was banned by the Ministry of Agriculture in April 2009. The German Court has not invalidated this ban. The ECJ, in its decision in Monsanto SAS

${ }^{79}$ GMO Safety: Genetic Engineering, Plants, Environment, Will It Now Be Impossible to Grow Genetically Modified Plants Outdoors?, GMO SAFETY (Sept. 15, 2011), https:// web.archive.org/web/20140826113853/http://www.gmosafety.eu/news/1351.honey-genetically-plants-ecj.html ${ }^{80} I d$.

${ }^{81} I d$.

${ }^{82} I d$.

${ }^{83} I d$.

${ }^{84} \mathrm{Id}$.

${ }^{85}$ Coexistence in Germany, supra note 58.

${ }^{86}$ Cantley, supra note 40 , at 75 .

${ }^{87}$ Id.

${ }^{88}$ Farming Regulations, supra note 61.

${ }^{89}$ GMO Safety: Genetic Engineering, Plants, Environment, An Appropriate and Well-Balanced Adjustment of the Conflicting Interests, GMO SAFETY (Nov. 24, 2010), https:// web.archive.org/web/20101213065454/www.gmo-safety.eu/ news/1253.genetic-engineering-act-federal-constitutionalcourt.html 
and Others v. French Minister for Agriculture and Fisheries $^{90}$ (September 8, 2011), invalidated the French ban, but it did not comment on whether other national cultivation bans for MON810 are legitimate. In this context, Germany's Federal Ministry of Food, Agriculture, and Consumer Protection have said that the ruling would not affect the German MON810 ban.

The government policy seems contradictory. The German government wants to exploit plant biotechnology but at the same time it wants the federal states to put in place their own measures, such as minimum separation distances between GM fields and conventional or organic fields. States such as Bavaria and North Rhine-Westphalia intended to use these new powers in a way that the cultivation of GM plants would be impossible. ${ }^{91}$

It is important to note that the European Commission passed new coexistence guidelines in 2010 and opened up the possibility for EU member states to issue hostile rules for the cultivation of GM plants. Prior to the 2010 guidelines, the coexistence measures issued by EU member states had to be appropriate for keeping adventitious presence below the EU-wide labelling threshold of 0.9 percent. $^{92}$ Besides adding cost to the cultivation and marketing of GM crops, the 2010 coexistence guidelines give member states the right to define GM-free zones where other measures to protect conventional/organic farming are not suitable. ${ }^{93}$ In the future, different federal states may have different minimum separation distances for the cultivation for GM crops or plants. Current German political and industry focus is in the field of white biotechnology. The production of renewable fuels and products for non-food use could be another area of interest. Such biotechnological products may receive a higher level of public acceptance as they do not enter into the food chain. ${ }^{94}$

\section{Spain}

Spain is the only country in the EU that grows GM plants on a large scale. Spain ranks sixth among maize-producing countries of the EU, with a total area of 340,000 hectares. In 2009, approximately one-fifth of the total Spanish maize acreage was used for $\mathrm{Bt}$ maize. Bt maize is grown in many regions of Spain and has been for over 10 years. From its initial conception, there was a gradual increase in acreage of Bt maize until it plateaued in 2008, reaching almost 80,000 hectares. Bt maize cultivated in Spain is used almost exclusively for animal feed. ${ }^{95}$

Spain has been growing Bt maize since 1998. In the first years of cultivation, the Bt176 strain of maize was marketed in Spain, which had been approved by the EU in 1997. Bt strains of maize are currently the only GM crop authorized for commercial cultivation in the EU. These strains are resistant to corn borer pests by virtue of the transgenic expression of a gene encoding the Bacillus thuringinesis toxin. After extensive experience with Bt176, Spain has become the EU member state with the highest adoption rate for this GM variety. In 1998, the planting of Bt176 corn in Spain reached 20000 hectares. This acreage remained fairly stable until the EU approved another $\mathrm{Bt}$ maize (transgenic event MON810) in 2003. By 2006, the coverage of Bt maize in Spain had increased to 53,000 hectares, which was 15 percent of the country's total maize acreage. ${ }^{96}$

Spain banned the cultivation of the insectresistant Bt176 maize in 2005. The Spanish government revoked the marketing authorization for Bt176 in April 2004. The Bt176 maize contains a gene which confers resistance to the antibiotic ampicillin. The ban was based on the EFSA report. According to this report, the EFSA's expert panel on genetically modified organisms had recommended that no new transgenic plants be approved if they contain genes conferring resistance to medicinally important antibiotics. ${ }^{97}$ The EFSA's GMO Panel recommended that GM plants should no longer contain genes which confer antibiotic resistance for antibiotics that are still regularly used to treat infectious diseases in human or animals. The Panel did note that in general it is extremely unlikely that the

${ }^{90}$ Monsanto SAS, supra note 48.
${ }^{91}$ GMO Safety: Genetic Engineering, Plants, Environment,
Plant Biotechnology: German States to Issue Their own
Cultivate Rules-GMO Bans Through the Back Door?,
GMO SAFETY (Sept. 22, 2010), https://web.archive.org/
web/20150610001153/http://www.gmo-safety.eu/news/1224
.plant-biotechnology-german-states-issue-own-cultivation-
rules-gmo-bans-door.html
${ }_{92}$ Id.
${ }^{93}$ Id.
${ }^{94}$ Cantley, supra note 40, at 75 .
${ }^{95}$ GMO Compass: Spain, Widespread Bt Maize Cultivation Pays Off in Spain, GMO ComPAss (Oct. 10, 2016), https:// web.archive.org/web/20161010165302/http:/www.gmocompass.org/eng/agri_biotechnology/gmo_planting/500.spain_ bt_maize_prevails.html

${ }^{96}$ Manuel Gomez-Barbero, Julio Berbel, and Emilio Rodriguez-Cerezo, Bt Corn in Spain-The Performance of the EU's First GM Crop, 26 NATURE Biotechnology 384-386 (2008) https://www.nature.com/articles/nbt0408384.

${ }^{97}$ EFSA: Safety Assessment of Antibiotic Resistance Markers, Spain: No Cultivation of Bt176 Maize, GMO SAFETY (May 11, 2004), https://web.archive.org/web/20101120215530/www .gmo-safety.eu/archive/217.spain-cultivation-bt176-maize.html 
cultivation and consumption of the GM plants with antibiotic resistance genes will lessen the efficacy of the particular antibiotics. However, the EU Deliberate Release Directive stipulated that the antibiotic resistance marker genes should be phased out. For this reason, the GMO Panel felt it would be prudent to take a close look at the safety of the different antibiotic resistance genes and recommend their disuse as a precautionary measure. ${ }^{98}$ However, as $\mathrm{Bt}$ maize (MON810) does not contain antibiotic resistance genes, it was not banned and continues to grow in Spanish fields. In Spain, the genetically modified maize is sold in the animal feed sector and 31 GMO varieties are listed in the Register of Commercial Plant Varieties, and include cultivars of maize, wheat, barley, soy, canola, and cotton. ${ }^{99}$

Spain has adopted two pieces of legislation to govern agriculture biotechnology and to comply with Council Directive (EEC) on the content use of genetically modified micro-organisms and the Deliberate Release Directive: Law 9/2003 on April 25, 2003 and Royal Decree 178/2004 on January 30, 2004. The Law 9/2003 established the regime for the confined use, release into the environment, and placing on the market of GMOs. The Royal Decree 178/ 2004 approved general rules for the implementation of Law 9/2003. ${ }^{100}$ In Spain, the coexistence regime consists of a draft Royal Decree based on the general principles set out in the 2003 Commission Recommendation. ${ }^{101}$

As of 2006, the farming community has been able to produce both GM and non-GM products. There have been no cases of litigation against farmers linked to adventitious presence in non-GM harvested material. ${ }^{102}$ "To date, no coexistence laws have been adopted in Spain; farmers rely on Good Agricultural Practices developed by APROSE and described in a brochure attached to each bag of GM maize. The guide referred to 25 meters of isolation distance or 4 buffer rows of non-GM maize in 2004 and 2005." 103

Ever since Spain started the cultivation of GM maize in 1998, there was a practice of coexistence and there were no legal issues. However, the Ministry of Environment and the Ministry of Agriculture, Fisheries, and Food (MAPA) presented the first draft of the Royal law on coexistence on July 19, 2005. This law governs the production of organic, conventional, and genetically modified crops. Under this law, specific coexistence regulations are made for the cultivation of various crops. According to these regulations, coexistence of conventional and genetically modified crops requires an isolation distance of 50 meters and four buffer plantings to assure that accidental mixing remains under the legal labelling threshold of 0.9 percent. ${ }^{104}$
The law further provides that every year the Ministry of the Environment and MAPA must devise a National Plan of Supervision to monitor and control all aspects of coexistence. The plan must include what inspections and analyses are required for the surveillance and evaluation of the coexistence legislation itself. Additionally, inspections and analyses are required for the cultivation and commercialization of products regulated through the coexistence legislation. The plan must also monitor the presence of GMOs in cultivated and non-cultivated zones adjacent to GMO cultivations to verify the efficacy of the required coexistence measures. ${ }^{105}$

The Royal law provides further specifications on the content and frequency of the inspections which must be contained in the Plan of Supervision. It provides that autonomous regions should inspect a percentage of the GM fields (the percentage is set by the Royal law) at least once in each cultivation season. These inspections will ensure farmers are using the proper isolation distances, using seeds properly, and maintaining good agricultural practices. In addition to this primary inspection, a second inspection must take place during the harvest. This is to verify that the physical separation and accurate labelling is maintained at all times. In addition to inspections and monitoring plans, the Plan of Supervision must also articulate the organization of information programs for farmers on coexistence. The information must outline recommendations for the control of GM crops and for the sowing of conventional crops. ${ }^{106}$

\footnotetext{
${ }^{98}$ Id.

${ }^{99}$ GMO Compass: Country Reports, Field Trials and Commercial Cultivation in Spain, GMO CoMPass (July 2, 2016), https://web.archive.org/web/20160702065406/http:/ www.gmo-compass.org/eng/news/country_reports/267.field_ trials_commercial_cultivation_spain.html

${ }^{100}$ Bodiguel et al., supra note 23 , at 179 .

${ }^{101} 2003$ Commission Recommendation, supra note 4.

${ }^{102}$ Dr. Rick Rouch, Stevens M. Brumbley, et al., Coexistence of Genetically Modified and Non-Genetically Modified Maize: Making the Point on Scientific Evidence and Commercial Experience, CropLife InTERnational (2006), at 6, http://biotechbenefits.croplife.org/paper/coexistence-ofgenetically-modified-and-non-genetically-modified-maizemaking-the-point-on-scientific-evidence-and-commercialexperience/

${ }^{103} I d$.

${ }^{104}$ GMO Compass: Country Reports, Coexistence in Spain, GMO Compass, (July 2, 2016), https://web.archive.org/ web/20160702064053/http:/www.gmo-compass.org/eng/news/ country_reports/268.coexistence_spain.html

${ }^{105}$ Id.

${ }^{106} I d$.
} 
The Spanish seed industry in 2006 accepted the recommendation in the draft coexistence legislation that says there should be a 50-meter isolation distance to ensure minimal contamination. ${ }^{107}$ Many field trials were conducted to determine if the 50meter isolation distance was in fact the minimum distance required to ensure threshold contamination levels are not exceeded. However, most of these trials were conducted with varieties of wheat and barley. In July 2006 the Ministry of Agriculture presented a second draft of the Royal law on coexistence. ${ }^{108}$ The second draft version of the Royal law recommended that the minimum isolation distance should be 220 meters rather than 50 meters as suggested in the first report. ${ }^{109}$ Law 30/2006 on seeds, nurseries, and phyto-genetic resources, ${ }^{110}$ created in July 2006, has provisions imposing penalties on the breach of its coexistence rule but it does not contain a specific enforcement mechanism. ${ }^{111}$

In Spain, the Constitution of Spain has separated the competency between the autonomous communities and the state (federal power). According to the Constitution of Spain, the autonomous communities enjoy competence in relation to agriculture. ${ }^{112}$ However, the Constitution of Spain confers on the state the competence to enact framework legislation in relation to economic strategy and health and environmental protection. ${ }^{113}$ The draft Royal Decree is based on these provisions in the Constitution. ${ }^{114}$

The National Biovigilance Commission is a consultative body on GMO issues for the Ministry of Agriculture, Fisheries, and Food. It was created by the Royal Decree 1697/2003 on December 12, 2003. ${ }^{115}$ Law 9/2003 and the Royal Decree 178/ 2004 outline the role of general state administration and of the autonomous communities with respect to authorizing confined use, deliberate release into the environment, and placing GMOs on the market. This includes the power of monitoring and enforcement. The General State Administration has the authority to allow the commercial use of GMOs, grant permission to import or export GMOs, and implement monitoring and enforcement in all areas for which they are competent. The autonomous communities are in charge of granting authorizations for deliberate release of GMOs, other than placing them on the market, and must implement monitoring and enforcement for tasks that do not fall within the competency of the state. ${ }^{116}$

In Spain, the Ministry of Agriculture approves and monitors biotech seeds for planting. The Ministry of Health and Consumer Affairs monitors and enforces labelling. The Ministry of the Environment monitors and enforces assessment of new GMO events and field trials, and applies penalties set by the 2003 law. In addition to these Ministries, there is also a committee and a council responsible for GMO seeds and GMO labelling. Representatives from the above ministries created a Biosafety Committee to study and propose changes. An Inter-ministerial Council has been created to review each biotech event and they are responsible for making final decisions on applications to cultivate biotechnology events. ${ }^{117}$ Recently, the Ministry of Agriculture, Fisheries, and Food and the Ministry of the Environment have been combined into the Ministry of the Environment and Rural and Marine Affairs. ${ }^{18}$

The legislative framework in Spain fails to resolve some important coexistence issues. The draft Royal Decree remains silent on "GM-free" zones and fails to address the possibility of bans or restrictions on the cultivation of GM crops when they are in conservation areas or near conservation areas. Nevertheless, many autonomous communities in Spain have declared themselves "GM-free" zones. ${ }^{19}$ The major criticism remains the complete omission of any provisions regarding liability for damage that results from the presence of GM material in excess of the threshold levels. The draft Royal Decree does not specify who incurs liability for damage or how farmers suffering from cross-contamination should be compensated. ${ }^{120}$ Also, there is nothing in the draft Royal Decree that indicates liability insurance or a guarantee fund will be required. Environmental organizations and some farmers groups have appealed to the government to include specific rules to fill in these obvious holes. ${ }^{121}$

\section{The United Kingdom}

In the United Kingdom, the government has been a strong advocate of modern biotechnology. In 2006, then Prime Minister, Tony Blair delivered a

\footnotetext{
${ }^{107} \mathrm{Id}$.

${ }^{108}$ Coexistence in Spain, supra note 105.

${ }^{109} \mathrm{Id}$.

${ }^{110}$ Official State Bulletin, BOE No. 178 of 27 July 2006.

${ }^{111}$ Bodiguel et al., supra note 23, at 185.

${ }^{112}$ Spanish Constitution, Art. 148.1(7)c (1978).

${ }^{113}$ Id. at Art. 149.1(13), 1491.1(16), and 149.1(23).

${ }^{114}$ Bodiguel et al., supra note 23 , at 185 .

${ }^{115}$ Royal Decree 1697/2003 of 12 December 2003, Official

State Bulletin, BOE No. 310 of 27 December 2003.

${ }^{116}$ Bodiguel et al., supra note 23 , at 180 .

${ }^{117}$ Cantley, supra note 40 , at 88 .

${ }^{118}$ Bodiguel et al., supra note 23, at 185 n.111.

${ }^{119}$ Id. at 187 .

${ }^{120} \mathrm{Id}$. at 188 .

${ }^{121} \mathrm{Id}$.
} 
speech to the Royal Society and articulated a vision of the UK as "a magnet for scientific endeavour." He also said that the UK is the location of half of all public biotechnology companies in Europe. ${ }^{122}$ Inside the EU's regulatory framework, the UK has always taken a pro-GM stance. In March 2009, the UK supported the European Commission's proposals to overturn national safeguard measures banning MON810 and T25. ${ }^{123}$ Despite governmental commitments, progress in implementing a coexistence regulation in the UK is surprisingly slow. The European Commission issued a 2009 Implementation Report and stated, "the development of a regulatory framework [in the $\mathrm{UK}$ ] is not envisaged in the near future as the cultivation of GM crops on their territory has been deemed unlikely to take place." ${ }^{24}$ Unlike France, the UK has not been condemned and fined by the European Commission or the ECJ for not implementing the EU Directives related to GMOs.

The situation in Northern Ireland, Scotland, and Wales is no better than the situation in England concerning GM cultivation. For example, the 2007 Manifesto of the Scottish National Party committed to a moratorium on the planting of GM crops in Scotland. In April 2009, the Scottish Environment Minister reaffirmed this sentiment stating that Scotland should remain "GM-free." 125 The Region of Wales and the Scottish Region of the Highlands and Islands were signatories to the 2005 Charter of Florence. ${ }^{126}$ In its March 9, 2004, policy statement, the UK government undertook the task of providing guidance to farmers who wished to establish voluntary "GM-free" zones. The UK government further stated they would do this in a manner that was "consistent with the EU legislation."127

In the United Kingdom, the cultivation of GM plants or crops for commercialization has not materialized yet. Regulation on coexistence is also not in force. The general public is suspicious of GM plants and crops due to possible risks relating to the environment and food safety. The UK government has adopted a cautious approach to this problem, and it is not fundamentally opposed to cultivating GM crops. The UK government has not allowed commercial production of GM crops until coexistence rules are enacted. The government has been extending the time frame for enacting coexistence rules. However, the UK has been conducting field studies of GMOs. ${ }^{128}$ As an EU member state, the UK is subject to all EU legislation relating to genetically modified plants or crops.

The Secretary of State for the Environment, Food, and Rural Affairs introduced the Genetically Modified Organisms (Deliberate Release) Regula- tions 2002 which came into force on October 17, 2002. It was enacted under the Environmental Protection Act 1990. ${ }^{129}$ The UK Environmental Protection Act (Part VI as amended) and the Genetically Modified Organisms (Deliberate Release) Regulation (1992) (as amended) incorporated EC Directive 90/220/EEC on Deliberate Release and Marketing of GMOs. ${ }^{130}$ In March 2004, the UK government set out its overall policy on GM crops. The government had concluded that there was no scientific evidence to support a complete ban on GM cultivation, but rather each proposed use had to be assessed on a case-by-case basis. The precautionary approach was to be continued by the government; authorizing commercial release of a GM crop only if evidence was presented that showed it did not pose an unacceptable risk to human health and the environment. ${ }^{131}$

The above policy stance of the UK government was created based on the findings of a three-year trial series called the Farm-Scale Evaluations (FSE). These trials examined the effects of pesticides at varying concentrations on species diversity. For maize, oilseed rape, and beets the goal of these trials was to discover whether the new systems with GMO crops and herbicides fare better in terms of ${ }^{122} I d$. at 189.
${ }^{123}$ Council of the European Union, Press Release, PRES/09/
53 , “2928th Council Meeting: Environment," EUROPA
PrESS ReLEASES RAPID (Mar. 2, 2009), http://europa.eu/ rapid/press-release_PRES-09-53_en.htm; see also Agra Europe Weekly No. 2351, Mar. 6, 2009, EP/1.

${ }^{124}$ Proposal for a Regulation of the European Parliament and of the Council on Jurisdiction, Applicable Law, Recognition and Enforcement of Decisions and Authentic Instruments in Matters of Succession and the Creation of a European Certificate of Succession (Brussels: EC, 2009).

${ }^{125}$ Bodiguel et al., supra note 23, at 189.

${ }^{126}$ Charter of the Regions and Local Authorities of Europe on the Subject of Coexistence of Genetically Modified Crops with Traditional and Organic Farming (Feb. 4, 2005).

${ }^{127} 418$ Parliamentary Debates HC (6th ser.) (Mar. 9, 2004) col. 1381 (UK); see also Bodiguel et al., supra note 23,at 194.

${ }^{128}$ GMO Compass: Country Reports, GMOs in the EU Member States, GMO Compass, (Mar. 31, 2017), https://web .archive.org/web/20170331074117/http://www.gmo-compass .org/eng/news/country_reports/

${ }^{129}$ GM crops and foods in Britain and Europe http://www .genewatch.org/sub-568547

${ }^{130}$ Lyle Glowka, Law and Modern Biotechnology: Selected Issues of Relevance to Food and AgriculTURE (Rome: Food and Agriculture Organization of the United Nations, 2003).

${ }^{131}$ Cantley, supra note 40 , at 96. 
agro-biodiversity than the pest control methods currently in use. ${ }^{132}$

At present, no commercial cultivation of GM crops has taken place in the UK. One authorization of GM maize (Chardon LL) was not used, as Bayer CropScience, the company involved, withdrew in 2004 and decided not to proceed under the strict conditions imposed. ${ }^{133}$ In November 2007, the Minister for the Environment affirmed that "[n]o commercial cultivation is expected in England for several years." 134

A few imported GMOs have been authorized for release in the EU, under Part C (commercialization) of Directive 2001/18/EC, including oilseed rape and maize. ${ }^{135}$ The GMO Safety: Genetic Engineering Plants Environment news website wrote on March 11,2004 , that

[t]he British government has agreed to the cultivation of herbicide-resistant maize, but only for a limited period of time and subject to certain restrictions.... None of the herbicideresistant varieties of sugar beet and oilseed rape tested in the Farm-Scale Evaluations will be permitted. Britain will oppose approval applications for these in the EU.... The cultivation of herbicide-resistant maize is permitted only under the conditions that proved advantageous for species diversity during the FSE trials. ... The cultivation of GM maize is also subject to appropriate coexistence 32 rules, which permanently safeguard the coexistence of agricultural systems with GM and non-GM crops. Britain aims to formulate these rules immediately.... Despite the government's decision, no herbicide-resistant maize will be grown in Britain for the time being. ${ }^{136}$

With regards to traceability and labelling, the UK government's stated position is that it supports labelling rules that are "practical, proportionate, enforceable and in line with its international obligations." Since 1999, labelling of GM products has been required in the UK. However, these labelling requirements have been displaced by two EU regulations covering traceability and labelling of GMOs. Both regulations were implemented in the UK on April 18, 2004, thereby displacing the old UK requirements. ${ }^{137}$

Few government departments and advisory bodies are involved in the regulatory process. The GM Policy, Science, and Regulation Unit of the Department for Environment, Food, and Rural Affairs (DEFRA) is responsible for control of the deliberate release of GMOs in England, developing national GM policy, transposing EU directives into national law, representing the UK in EU and international negotiations on the environmental safety of GMOs, commissioning and disseminating scientific research on genetic modification, and assessing the environmental risk of the contained use of GMOs. The Health and Safety Executive (HSE) regulates the contained use of GMOs. The Plant Varieties and Seeds Unit controls the authorization of GM seeds for the National Seed List. The Food Standards Agency (FSA) is responsible for the assessment of GM food and it also monitors provisions for traceability and labelling of GM food and feed. ${ }^{138}$

UK ministers and other relevant bodies receive advice from the Advisory Committee on Release to the Environment (ACRE) concerning the possible environmental and human health implications of all experimental and commercial releases of GMOs. ACRE is an independent scientific committee which includes leading academic scientists among others. The Advisory Committee on Novel Foods and Processes (ACNFP) and the Advisory Committee on Animal Feedingstuffs (ACAF) are similar to ACRE and advise the UK ministers on GMOs that will be specifically used in food or animal feed. DEFRA's GM Policy, Science, and Regulation Unit deals with international initiatives concerning GMOs including work undertaken by the Organisation for Economic Co-operation and Development (OECD) on biotechnology, legislative proposals in the EU, and work on biosafety undertaken by UNEP. DEFRA is also the lead organization on the negotiation and implementation of international legislation and treaties relating to GMOs. ${ }^{139}$

On March 29, 2017, the United Kingdom submitted notification of its intention to withdraw from the European Union. On January 23, 2018, the EU issued a notice to stakeholders that all Union

\footnotetext{
${ }^{132}$ GMO Safety: Genetic Engineering, Plans Environment, British Government Allows the Cultivation of GM Maize, GMO SAFETY (MAR. 11, 2004), https://web.archive.org/ web/20131104104151/http://www.gmo-safety.eu/archive/ 209.british-government-allows-cultivation-maize.html ${ }^{133}$ Bodiguel et al., supra note 23, at 189.

${ }^{134} 467$ Parliamentary Debates HC (6th ser.) (Nov. 8, 2007), col. 15WS (UK) (Phil Woolas, Minister for the Environment).

${ }^{135}$ Cantley, supra note 40 , at 97.

${ }^{136}$ British Government Allows, supra note 133.

${ }^{137}$ Cantley, supra note 40, at 98.

${ }^{138}$ Id.

${ }^{139} \mathrm{Id}$.
} 
primary and secondary law will cease to apply to the United Kingdom from March 30, 2019. "The EU rules in the field of genetically modified food and feed and the deliberate release of genetically modified organisms into the environment no longer apply in the United Kingdom." ${ }^{140}$ However, the ongoing "Brexit Saga" has not yet come to any resolution, and is unlikely to do so in the coming months. ${ }^{141}$

\section{Portugal}

In Portugal, GM Bt maize was cultivated for the first time in 1999. The cultivation of Bt maize covered approximately 1,300 hectares of land that year. The cultivation of Bt maize in Portugal was stopped for five years following the quasi-moratorium of the EU. Portugal did not cultivate biotech crops during the five years following the AGMIN Dispatch dated December 27, 1999. This dispatch suspended the sale or use of biotech seeds listed in the National Seed Catalogue (NSC) and banned biotech seed trials with a commercial purpose. ${ }^{142}$ However, testing of seeds for noncommercial purposes remained permissible, subject to approval by the Environment Institute (IA) of the Environment Ministry. ${ }^{143}$ Portugal began planting genetically modified corn again in 2005. In Portugal, Bt maize was planted in about 770 hectares in 2005 and about 4,200 hectares in 2007. ${ }^{144}$ No safeguard measures have been invoked relating to the planting of biotech crops, so all varieties which are approved in the EC catalogue can be planted in Portugal. ${ }^{145}$

Multinationals and local manufacturers with higher-profile brands have eliminated biotechderived products. When feed is biotech-derived in any form, the feed association has instructed its members to label the feed with the words "contains GMO." 146 The Transgenic Out of the Plate (TOTP) movement leads and coordinates all anti-biotech lobbying in Portugal. TOTP is comprised of numerous organizations from large scale environmental groups to small local farmers. Numerous highprofile events have brought TOTP greater recognition within the public eye. ${ }^{147}$

The general public seems in favor of genetically modified plants and crops. Farmers in Portugal have grown almost $60 \%$ more GM maize in 2011 compared to 2010. The total number of hectares has increased by almost 3,000 to a total of 7,843 hectares in 2011. Compared to the other continents, with the exception of Australia, the EU has approved far fewer GM products, effectively decreasing a farmer's competitiveness. ${ }^{148}$ One Portuguese farmer who has been growing maize reiterated this belief saying, "We are all competing for the same market but with different rules. Having access to more GM crops would improve the long-term sustainability of Portuguese and European agriculture. But once again Europe and Portugal are trailing far behind the rest of the world." 149

Farmers are not the only group in Portugal who believe GM crops should not only be allowed to be cultivated, but their cultivation should be encouraged. Pedro Fevereiro, an investigator and professor of plant cell biotechnology and President of the Centre for Biotechnology Information (CiB Portugal), stated:

The following agricultural years will witness important climatic changes, which will be followed by abiotic and biotic stresses, to be withstood by the different crops, especially in the Mediterranean area. Genetically modified cultivars are one of the already-available technologies to cope with the difficulties to be faced. Productivity needs to be increased, and this technology is already proven to enable cultivars to attain their maximum potential, protecting the plants and the environment against pests, diseases and weeds, while creating products that are safe and healthy. These benefits are being experienced and accumulated all over the world for more than fifteen years. It is time for the European farmers to profit from this technology. ${ }^{150}$

\footnotetext{
${ }^{140}$ European Commission Directorate-General for Health and Food Safety, Notice to Stakeholders of the United Kingdom and EU Rules on Genetically Modified Food and Feed and the Deliberate Release of Genetically Modified Organisms into the Environment (Brussels, January 23, 2018).

${ }^{141}$ At the time of writing, the elections for the European Parliament are being undertaken, with UK participation pending withdrawal from the Union. If the UK successfully withdraws it may be that the nation will take a more active approach to the adoption of GM crops.

${ }^{142}$ Leonor Ramos, USDA Foreign Agricultural Service, Portugal Biotechnology Annual 2005, No. PO5017 (Aug. 4, 2005), available at https://apps.fas.usda.gov/gainfiles/ 200508/146130489.pdf

${ }^{143} \mathrm{Id}$.

${ }^{144}$ Theodoros Skevas, Justus Wesseler, and Pedro Fevereiro, Coping with Ex-Ante Regulations for Planting Bt Maize: The Portuguese Experience, 12(1) AgBioForum 60, 61 (2009). ${ }^{145}$ Ramos, supra note 143 .

${ }^{146} \mathrm{Id}$.

${ }^{147} \mathrm{Id}$.

${ }^{148}$ United States Department of Agriculture Agricultural Biotechnology Annual, 2016 https://gain.fas.usda.gov/Recent \%20GAIN\%20Publications/Agricultural\%20Biotechnology \%20Annual\%20_Madrid_Portugal_12-5-2016.pdf.

${ }^{149}$ Id.

${ }^{150} \mathrm{Id}$.
} 
Regulation. Being a member state of the EU, Portugal is subject to the EU regulations relating to GM plants and crops. As such, Portugal is obligated to transform the provisions of EU regulations into its domestic law. On September 21, 2005, Portugal enacted the Portuguese Coexistence Regulations issuing the Decree-Law No. 160/2005 of September 21, 2005. This Law was, based on the principles established by the 2003 Commission Recommendation $(2003 / 556 / \mathrm{EC}),{ }^{151}$ to regulate biotechnological production in Portugal. The coexistence regulation aims to achieve a viable coexistence of GM crops with conventional and organic crops. Accordingly, it defines a set of agricultural practices to achieve its aim. Local authorities justified the need for a coexistence law based on the precautionary principle and public concern over GMOs. The coexistence law sets technical cultivation parameters, inter-crop minimum distances, buffer zones, procedural requirements, and facilitates the designation of biotechnology-free zones. ${ }^{152}$ There is also a provision which creates a compensation fund for economic losses suffered as a result of cross-contamination. ${ }^{153}$

The Portuguese coexistence law establishes a mandatory national registration system for GMOs. GM farmers must provide notification 20 days in advance of cultivation that their fields contain GMOs. Notifications are first sent to the Regional Agricultural Directorates (DRA), then to the Directorate General for Crop Protection (DGPC) for evaluation, and finally, the notification is disclosed to the public. GM farmers must also provide the parcel ID, size and location of the field, information that concerns identification of the GMO, and details of any precautionary measures that are being taken. In addition to this, farmers are required to attend compulsory training courses dealing with the coexistence of GM, conventional, and organic crops. The DGPC is responsible for the publication, evaluation, and approval of the program contents and of proposed training courses. The seed companies or farmers' organizations are responsible for the organization of these courses and who will be teaching the courses. The trainers that are chosen must have at least a bachelor's degree and a trainer's certificate in the field of coexistence. Finally, farmers who intend to plant GM crops must inform their neighbors and the farmers they share their equipment with of their intention in a letter. In terms of monitoring, the farmers must keep records of their production process. $^{154}$

The coexistence law also establishes technical segregation measures. These measures include isolation distances from non-GM crops, barriers and pollen traps, buffer zones, production planning and seed handing and /or storage. For Bt maize, the coexistence law requires a minimum distance of 200 meters between Bt and conventional corn plots, and a 300-meter distance between $\mathrm{Bt}$ and organic maize plots. In an alternative to segregation distances, GM farmers may choose a different time for seeding or make use of a $20 \%$ buffer zone. These segregation measures are mandatory but can be amended according to local conditions. The coexistence law also has segregation measures for transport, handling, and margin harvesting. ${ }^{155}$

The coexistence law also establishes liability provisions. The DGPC finances a compensation fund to cover the accidental contamination of nonGMO crops due to pollen drift. The DGPC has posed a $€ 4$ tariff on the price of standard GM seed bags to finance this compensation fund. Penalties have been established for those farmers who do not comply with the coexistence law. For administrative infringements, individuals will be required to pay $€ 205$ while legal entities will be required to pay $€ 2,500$. For those who do not comply with the segregation measures, individuals will be fined $€ 3,700$ while legal entities will be fined $€ 44,800$. $^{156}$

The DGPC is responsible for the enforcement of the segregation measures mentioned above. The DGPC must monitor the implementation of the coexistence legislation in cooperation with regional agricultural authorities. Additionally, the coexistence law provides a regulatory framework for regions which are to be GM free. The GM-free areas will be subject to regulation through a joint order of the Minister for Agriculture, Rural Development, and Fisheries and the Minister for the Environment, Land Management, and Regional Development. There are a number of fixed and variable costs for GM growers. Registration costs, training courses, and record keeping are fixed costs independent of the field size. The required segregation measures, minimum distance requirements, and information obligations increase with field size. ${ }^{157}$

\footnotetext{
${ }^{151} 2003$ Commission Recommendation, supra note 4.

${ }^{152}$ Ramos, supra note 143.

${ }^{153}$ GMO Safety: Genetic Engineering, Plants, Environment, A European Patchwork, GMO SAFETY (Feb. 22, 2010), https://web.archive.org/web/20151122001141/http://www.gmosafety.eu/coexistence/449.european-patchwork.html (visited Dec. 15, 2011).

${ }^{154}$ Skevas et al., supra note 145 , at 62 .

${ }^{155} \mathrm{Id}$.

${ }^{156} \mathrm{Id}$.

${ }^{157}$ Id. at 63 .
} 
The coexistence regulations and the responsibilities they impose are central to a farmer's decision to cultivate GM crops. The coexistence regulations impose extra costs on potential GM farmers, which, as mentioned above, can act as a deterrent for would-be GM farmers. Soregaroli and Wessler showed that the strict minimum distance requirements actually discriminate against smaller farms. ${ }^{158}$ Additionally, almost half of all surveyed maize farmers stated that the regulations are rigid and difficult to apply. The difficulty of the coexistence regulation's application and the deterrent effect it has on farmers seems to hamper Bt maize adoption, thereby reducing its presence. This would therefore seem to reduce, rather than support, coexistence. ${ }^{159}$

In Portugal, the Environment Ministry is responsible for the implementation of GM-related EU legislation ${ }^{160}$ and for the assessment of GMO-related risks to the environment. The Environment Ministry (PEM) represents the government at the EU Environment Ministers council level. The PEM receives technical recommendations from the Environment Institute (IA) and political advice from the Ministry's Office of International Regulations (GRI). Taking into consideration advice from both parties, the PEM will develop its national positions. ${ }^{161}$

The Agricultural Ministry (AGMIN) is responsible for GM submittals under the Food and Feed Regulation. ${ }^{162}$ The AGMIN's food monitoring and quality general directorate (DGFCQA) is responsible for preparing biotech dossiers, issuing technicallevel recommendations to the government of Portugal, and representing Portuguese authorities at technicallevel meetings of specialized EU Committees. ${ }^{163}$ Directorate-General for the Protection of Cultures (DGPC) of the Ministry of Agriculture, Rural Development, and Fishing is responsible for the certification, quality, and monitoring of GM planting. It also conducts experimental research. The Directorate-General for the Monitoring and Quality Food Control of the Ministry of Agriculture, Rural Development, and Fishing is responsible for the release of all food products. ${ }^{164}$

In 2004, the Portuguese government instituted the Biosafety Committee which was intended to provide coordinated technical support to government decision making on new biotechnology seed requests. However, this Biosafety Committee never operated in Portugal.

\section{The Netherlands}

In the Netherlands, the cultivation of GM plants is a controversial issue, and both the general public and politicians are participating in GMO issues. In the history of the EU, the Netherlands is the only country that involved all stakeholders in the process of developing coexistence guidelines and developed coexistence guidelines with their consensus. In 2005, stakeholders in the Netherlands came to a consensus on coexistence rules. To date, GM crops have never been commercially cultivated in the Netherlands. However, the Dutch Ministry of Agriculture, Nature, and Food Quality conducted an experiment on coexistence between GM and conventional crops. The experiment had been conducted with MON810 at six different locations in the Netherlands in 2006 and 2007. This experiment marked the first planting of authorized GM crops in the Netherlands. ${ }^{165}$ While GMO market acceptance in the Netherlands is higher than any of the other EU countries, the opponents of GMOs are still very active in the Netherlands.

Dutch Minister of Agriculture, Nature, and Food Quality Cees Veerman ${ }^{166}$ said, at the EU Conference on Coexistence of Genetically Modified, Conventional and Organic Crops-Freedom of Choice on April 5, 2006 in Vienna, that "the government should not start by imposing rules or sanctions, but first give the parties involved the opportunity to find a solution. Our starting point therefore was a yearlong dialogue in and with society: a dialogue that managed to turn emotions - at least most of them-into practical terms of application/or nonapplication of biotechnology." 167

\footnotetext{
${ }^{158}$ Beckmann, Volker \& Soregaroli, Claudio \& Wesseler, Justus, 2006. Governing the Co-existence of GM Crops: Ex-Ante Regulation and Ex-Post Liability under Uncertainty and Irreversibility, Institutional Change in Agriculture and Natural Resources Discussion Papers 18845, Humboldt University Berlin, Department of Agricultural Economics.

${ }^{159}$ Skevas et al., supra note 145 , at 63.

${ }^{160}$ Deliberate Release Directive, supra note 3.

${ }^{161}$ Ramos, supra note 143.

${ }^{162}$ Food and Feed Regulation, supra note 10.

${ }^{163}$ Ramos, supra note 143.

${ }^{164}$ Future Food: What Is Legal?, Bionet, https://web.archive .org/web/20101120110843/www.bionetonline.org/english/ content/ff_leg2.htm (visited Dec. 14, 2011).

${ }^{165}$ GMO Compass: Country Reports, Field Trials and Commercial Cultivation in the Netherlands, GMO CoMPAss (July 2, 2016), https://web.archive.org/web/2016070206 4925/www.gmo-compass.org/eng/news/country_reports/240 .field_trials_commercial_cultivation_netherlands.html

${ }^{166}$ Cees Veerman, Minister of Agriculture, Address (speech delivered at the Nature and Food Quality at the EU Conference on Coexistence of Genetically Modified, Conventional and Organic Crops-Freedom of Choice, Apr. 5, 2006). ${ }^{167}$ Id.
} 
The Dutch Minister further stated that,

I am convinced that not only organic farming, but also conventional and GMO production have their place in sustainable agriculture. The Netherlands is therefore not opposed to the principle of gene technology. This is not only my view; it is the general feeling in the country. As I said, we organised a broad public debate; this as early as 2001. The debate showed that the Netherlands are willing to exploit the opportunities offered by biotechnology for sustainable agriculture and a better environment. But only under the strict conditions that it is safe and that the consumer is able to choose. ${ }^{168}$

\section{The Minister stated,}

I do not believe that the government should stand in the way of new technological developments. I do think, however, that the government has to protect the public interest on questions of health, safety and freedom of choice, as well as guarding specific interests, such as those of organic growers. But I did not necessarily want to lay down these guarantees in law. It was my wish to give the parties themselves the opportunity to make agreements. This stemmed from my belief that it would lead to more workable guidelines, which could rely on broader support and which - if regulation had to be introducedwould also be easier to enforce. And so that's the way we did it in the Netherlands. In 2004 I asked the various parties from the GMO, traditional and organic sectors to put their heads together. I did this because I am convinced that it is they who are primarily responsible for putting a workable solution in place and creating support. ${ }^{169}$

In the Netherlands, an umbrella committee known as the van Dijk Committee, named after its chairman, was set up to draw up coexistence rules. The LTO, an agriculture organization of the Netherlands, and Biologica, the umbrella organization for organic agriculture, worked together to prepare an agreement on coexistence. The Platinum NL Association of Plant Breeders and Platform Earth Farmer Consumer also joined the previously mentioned groups to draw up coexistence rules. The Committee was able to reach an agreement between conventional and organic farmers, seed producers, plant breeders, consumers, industry, environmental groups, and others involved in agriculture in the Netherlands. They agreed to guidelines for growing GM crops in the Netherlands. The plan prepared by the Committee also received support from the association of organic farmers. The Committee presented a "Coexistence in Primary Production" report to the government (Minister of Agriculture) in November 2004. On the basis of that consensus agreement, the Central Market Association for Arable Farming produced a coexistence decree. ${ }^{170}$ The Dutch government submitted this decree to the EU for notification and a fund was set up to cover liability claims. Detailed rules governing these claims were established by various members of the coexistence working group in July $2008 .^{171}$

The GMO register of the Ministry of Housing, Spatial Planning, and the Environment registers commercial planting of GMOs in the Netherlands. ${ }^{172}$ Many field tests on GM potato, sugar beet, rutabaga, cabbage, carrot, maize, rapeseed, chicory, tomato, chrysanthemum, sunflower, carnation, violet, and apple were conducted during the 1990s. However, the number of fields test dropped off significantly after 2000. In 2006, field trials were being carried out by two biotech companies and one research institution. BASF Plant Science conducted test plantings of its GM potatoes at three sites. AVEBE, a Dutch starch company, tested its GM amylopectin potato at several sites in northern Holland. Plant Research International, part of Wageningen University and Research Centre, conducted field trials with fungus resistant GM apples. ${ }^{173}$

The Main Board of Arable Crops has set up regulations for coexistence based on the coexistence agreement:

- Farmers wishing to grow GM crops must notify their neighbors in a public register before February 1 . Likewise, farmers intending to produce GM-free crops must inform neighboring farmers producing GMOs.

- Farmers must comply with prescribed codes of practice; at all stages of cultivation appropriate

\footnotetext{
${ }^{168} I d$.

${ }^{169} \mathrm{Id}$.

${ }^{170}$ GMO Safety: Genetic Engineering, Plants, Environment, National Coexistence Rules: The Netherlands, GMO SAFETY, http://www.gmo-safety.eu/coexistence/418.netherlands.html.

${ }^{171}$ Country Reports Coexistence in the Netherlands https:// web.archive.org/web/20140227020726/http://www.gmocompass.org/eng/news/country_reports/

${ }^{172}$ Field Trials, supra note 166.

${ }^{173} \mathrm{Id}$.
} 
measures must be taken to avoid mixing GM and GM-free crops. These include thoroughly cleaning machinery, maintaining separation distances, and implementing segregated storage and transport.

- Minimum separation distances have been set for potatoes, sugar beet, and maize. For GM fields adjacent to conventional fields, the separation distances are three meters for potatoes, 1.5 meters for sugar beet, and 25 meters for maize. If the GM field is adjacent to a field with a certified GM free crop (as is the case for organic farming), the minimum separation distances increase to 10 meters for potatoes, three meters for sugar beet, and 250 meters for maize. ${ }^{174}$

The possibility of cross-contamination between GM crops and conventional crops is considered remote if the proposed codes of practice for coexistence are upheld. If a grower does not adhere to these coexistence measures, cross-contamination and subsequent economic losses could occur. If such an event happens, the grower who did not adhere to the coexistence measures can be held liable under the Dutch Civil Law for any losses caused by the presence of GM material. Where the GM grower abides by the co-existence measures but crosscontamination still occurs, a public fund compensates the conventional farmer for any loss. The details of this fund are currently being worked out, but it is known that a fund will be established for each individual crop. ${ }^{175}$

Compliance is implemented by certified Good Agricultural Gap schemes. The Main Board of Arable Crops may reproach those farmers who do not comply with coexistence measures and even issue fines. ${ }^{176}$ Extensive monitoring is planned for evaluating the effectiveness of the coexistence measures. The coexistence measures may be changed or augmented where the results of the monitoring would deem change appropriate. The van Dijk Committee has made suggestions for a monitoring protocol which includes details on sampling, detection, reporting, and consequences. ${ }^{177}$

\section{Belgium}

Belgium has transformed Directive 2001/18/ $\mathrm{EC}^{178}$ into its domestic legislation. The legislative framework for experimental use and commercialization of GMOs includes both the Belgium Royal Decree of February 21, 2005, on the deliberate release into the environment and the placing on the market of GMOs or GMO-containing products, ${ }^{179}$ and the Cooperative Agreement Between the Federal State and the Regions on the Administrative and Scientific Coordination Concerning Biosafety. ${ }^{180}$ However, the Royal Decree was only adopted after some delay. The delay was caused by a disagreement about the way in which the EU directive should be transformed into Belgian law. The then Minister of Consumer Affairs, who was a member of the Green Party, created a preliminary draft of the legislation that went further than the EU directive. The major point of contention was that the preliminary draft required an ethical assessment be made for each individual application in addition to the health and environmental risk assessment required by the EU directive. A decision on the matter could not be reached until a new government was elected. The new government, without the Green party, decided to transform the EU directive as it was and dropped the provision requiring an ethical assessment. ${ }^{181}$ In fact, the ECJ, in the 2004 Commission v. Belgium ${ }^{182}$ case, condemned Belgium for delays in the transposition of Directive 2001/18/EC.

In Belgium, the federal law does not allow the release of GMOs into the environment without first obtaining authorization for such an experiment. When a person seeks authorization for experimental release of GMOs into the environment, that authorization is delivered by the federal administration on the basis of advice from the Biosafety Advisory Council. The regional administration also participates in the decision-making process with the federal administration. Similarly, placing GM plants or crops or novel food onto the market is also restricted in Belgium, and authorization must be

\footnotetext{
${ }^{174}$ GMO Compass: Country Reports, Coexistence in the Netherlands, GMO CoMPAss (July 2, 2016), https://web .archive.org/web/20160702065414/http:/www.gmo-compass .org/eng/news/country_reports/239.coexistence_netherlands .html

${ }^{175} I d$.

${ }^{176} I d$.

${ }^{177} I d$.

${ }^{178}$ Deliberate Release Directive, supra note 3.

${ }^{179}$ Royal Decree of 21 February 2005, Belgian Official Journal (Feb. 24, 2005). Text is available in French and Dutch at https://www.biosafety.be/sites/default/files/arogm_2005.pdf

${ }^{180}$ Cooperation Agreement on Biosafety, https://www.bio safety.be/content/cooperation-agreement-biosafety (Mar. 28, 2012).

${ }^{181}$ Prof. Dr. L. Lavrysen, Belgian Report (Paper delivered at the Avosetta Meeting on GMOs, Sept. 29-30, 2006), at 3.

${ }^{182}$ Case C-417/03, Commission v. Belgium, [2004] O.J. C284/5.
} 
obtained from the EU before commercialization can take place. At the federal level, the Federal Public Service (FPS) Health, Food Chain Security, and Environment is involved in these processes.

In Belgium, all issues relating to agriculture come under the scope of the regional authorities. Issues like regulation of GMOs and food safety are federal policy issues. Human health, animal health, and the environment are also federal issues. Hence, coexistence is considered as part of agriculture policy, and not as an environmental biosafety issue. In the Wallonia region of Belgium, the framework of coexistence regulation came into operation in August 2008 and in the Flanders region in May 2009. The coexistence legislation was enacted to manage the cultivation of GM plants and crops in each region. So far, both regions do not have any experience with large-scale commercial cultivation of GM plants. Interestingly, in Belgium there is no policy aimed at establishing GM-free zones. ${ }^{183}$

In the Flanders region, the decree outlines the administrative procedure for GMO applications, conditions to be fulfilled by GM growers, the creation of the coexistence committee and a compensation fund, GM-free zones, record keeping, liability monitoring, supervision, control, and administrative fines. The decree requires farmers and contractors who want to work with GM crops to follow a specific training program. An additional requirement for farmers wanting to work with GM crops is that they must notify the competent authority, neighboring farmers, the owner of the plot of land, and any other person who is directly affected by the crop. To be considered a "neighboring farmer" the farm must be within the isolation distance which varies depending on the type of plant being cultivated. For maize cultivations, the isolation distance is 200 meters. Any neighboring farmers within the isolation distance have the right to object to the proposed GM crop, citing economic interest. All objections are reviewed by the coexistence committee and their decision on the matter is final. ${ }^{184}$

To finalize the GMO application procedure, potential farmers must pay a contribution for each GM crop to the compensation fund, as created by the decree. The amount of each contribution is different for each type of crop and is proportional to the plot size. The purpose of this fund is to indemnify any conventional or organic farmers that suffer an economic loss due to adventitious mixing from GM crops. Economic loss is defined as the difference in the market price between a non-GM and a GM product. The way economic loss is defined would normally allow a conventional farmer to recover from a GM farmer for accidental adventitious mixing even though the GM farmer has complied with all the regulations. The compensation fund was created to help GM farmers in this exact situation. If however, the GM farmer has not complied with the coexistence legislation, the fund will not be used to indemnify any conventional or organic farmers for their economic loss. The GM farmer responsible for the adventitious admixture will remain liable under the Belgian tort law. A coexistence committee has been created to hear claims by neighboring farmers that they should receive compensation from the fund for economic loss due to admixture. ${ }^{185}$

The decree also allows the government to create GM-free zones. To create a GM-free zone, an official request by all farmers cultivating crops in that area must be submitted. In addition to the request, other conditions must be met, including a minimum area requirement. Once an area has been declared a GM-free zone, the competent authority is given the right to verify compliance with the legislation. In exercising this power the competent authority may question any relevant person, inspect any documents or fields, and take physical samples of the crops. The competent authority must also keep records of any GM crops in a register which is accessible to the public in accordance with the Aarhus Convention on Access to Information, Public Participation in Decision-Making and Access to Justice in Environmental Matters. ${ }^{186}$

Noncompliance with any of the coexistence rules is penalized with an administrative fine. The penalty is proportional to the seriousness of the infringement, ranging from $€ 200$ to $€ 1,000$. The fines are deposited in the compensation fund to be used for indemnifying any conventional or organic farmers for economic loss due to adventitious admixture. ${ }^{187}$

In the Wallonia region, the coexistence rule has a provision concerning the possibility of creating GMO-free zones as well as a provision concerning a liability fund. Like Flanders, Wallonia's coexistence legislation contains mandatory notification to the government, neighboring farmers, and owners of the plot, a contribution to a compensation fund, a

\footnotetext{
${ }^{183}$ Lavrysen, supra note 182 , at 12.

${ }^{184}$ Cindy Boonen, "The Regulatory Approach Towards Coexistence in Flanders, Belgium," (Paper delivered at the Fourth International Conference on Coexistence Between Genetically Modified (GM) and Non-GM Based Agricultural Supply Chains, Nov. 10-12, 2009), at 3.

${ }^{185} I d$. at 4.

${ }^{186}$ Id.

${ }^{187}$ Id.
} 
detailed publicly available register of GM crop locations, legal prosecution, obligatory cleaning of machinery, and isolation distances of 600 meters for maize. Currently, Flanders, Wallonia, and the Netherlands have started discussions on possible cross-border issues. They are trying to identify these problems so a simple solution may be put in place. ${ }^{188}$

\section{Italy}

In Italy, the agriculture sector falls within the exclusive legislative powers of the regions as the Constitution of Italy placed agriculture under regional control. ${ }^{189}$ There is a clash between the central government and several regions on the issue of coexistence. ${ }^{190}$ Many regions enacted bills to declare themselves GM-free: Regione Emilia-Romagna, Regione Lazio, Regione Marche, Regione Sardegna, Regione Toscana, and the Provincia Autonoma di Bolzano signed the Charter of Florence. ${ }^{191}$ As of 2008, 16 of the 20 Italian regions have declared themselves GM-free. "In general, Italy has followed EU policies on agricultural technology. However, it has maintained a more restrictive position when it comes to what seeds may be planted, coexistence laws, and the deliberate release of GM" crops into the environment. ${ }^{192} \mathrm{GM}$ products are not available at the retail level in the Italian market. Sixteen EU member countries have adopted coexistence legislation; ${ }^{193}$ however, there are currently no coexistence laws in place in Italy. This makes it impossible to start legal commercial cultivation of genetically modified crops. ${ }^{194}$ In Italy, a national initiative of 28 organizations launched National Consultations on GMOs in 2007, and collected three million votes against GMOs from September 15 to November 15, 2007. The National Consultations represented farmers; large distribution companies; small and medium-sized businesses; and consumer, environmental, scientific, cultural, and international cooperation interest groups.

As of 2009, there was no consensus among key Ministers on GMOs. Regions have adopted technical agreements on coexistence, but they are waiting for a political settlement. Coexistence technical guidelines, which are a baseline for regional coexistence measures, were issued on October 2007. Italy has ratified the Cartagena Protocol on Bio-safety. ${ }^{195}$ Italian Law No. 27 of January 15, 2004 provides the legal basis for the implementation of the Cartagena Protocol.

In Italy, EU regulations and directives set the regulatory framework for biotech products. The first EU Directive 90/220/EEC on the deliberate release of GMOs into the environment was ratified in 1993 in Italy by Italian Legislation Decree No. 92. Later, Directive 90/220/EEC was repealed by Directive 2001/18/EC. Directive 2001/18/EC on the deliberate release of GMOs into the environment was transformed into Italian law by Italian Decree No. 224 of July $8,2003 .{ }^{196}$ The experimental release and placing on the market of a GMO is mainly governed by the provisions of Legislative Decree No. 224 in Italy.

Italy, by the Decree of August 2000, suspended the trade in and use of products derived from four GM maize varieties (MON810 from Monsanto; T25 from Bayer Crop Science; Bt11 from Syngenta; and MON809 from Pioneer), which had been noted under the simplified procedure for products considered as "substantially equivalent." Italy invoked the safeguard clause (Article 12) under Regulation (EC) No. 258/1997 on novel foods in August 2000. The EU Commission sought an opinion from the Scientific Committee for Food (SCF) and, in September 2000, the Scientific Committee concluded that the Committee lacked detailed scientific grounds to support that the novel food endangered human health. The EU Commission asked the Italian government to repeal the Decree of August 2000. Italy replied that the safeguard measures no longer applied as the new provisions relating to the placing on the market and labelling of GM products of Regulation (EC) No. 1829/2003 of the European Parliament and of the Council on genetically modified food and feed ${ }^{197}$ overruled its effect on the suspension of trade. ${ }^{198}$

\footnotetext{
${ }^{188} I d$. at 7.

${ }^{189}$ Constitution of the Italian Republic, Art. 17 (1948).

${ }^{190}$ Bodiguel et al., supra note 23, at 174 .

${ }^{191}$ Charter of the Regions and Local Authorities of Europe, supra note 127.

${ }^{192}$ Cantley, supra note 40 , at 77 .

${ }^{193}$ Alessandro Chiarabolli, Coexistence of Genetically Modified Crops with Conventional and Organic Agriculture: The Italian Situation, 30(6) BiotechNology L. ReP. 675 (2011).

${ }^{194}$ Id.

${ }^{195}$ Cartagena Protocol, supra note 16.

${ }^{196}$ Italian Decree No. 224 of 8 July 2003: Implementation of the Directive 2001/18/EC on the Deliberate Release of Genetically Modified Organisms into the Environment.

${ }^{197}$ Food and Feed Regulation, supra note 10.

${ }^{198}$ Questions and Answers on the Regulation of GMOs in the European Union, EuROPA, available at https://web.archive .org/web/20131225004820/ec.europa.eu/food/food/bio technology/gmfood/qanda_en.pdf (visited Dec. 12, 2011).
} 
When Italy banned novel food, the ECJ, in Monsanto Agricoltura Italia SpA v. Prezidenza del Consiglio dei Ministri, ${ }^{199}$ interpreted Article 12 of the Regulation 258/97 with a particular emphasis on the precautionary principle. On the issue of GMO foodstuff bans made by Italy pursuant to the measures of Article 12 of Regulation 258/97, the Court ruled that "it is apparent that, in the light of the precautionary principle, the implementation of such measures is necessary in order to ensure that novel foods do not present a danger for the consumer." 200 Article 12 of the Regulation 258/97 allows member states to temporarily ban products if there are "detailed grounds for considering that the use of a food or a food ingredient ... endangers human health or the environment." Article 12 of the Regulation 258/97 is a codified version of the precautionary principle.

The European Commission passed nonbinding guidelines on coexistence in $2003 .^{201}$ As EU member states were free to decide whether and how to regulate coexistence when growing either GM or conventional crops, Italy issued Government Legislative Decree No 279/2004, which was passed by the Parliament. ${ }^{202}$ Government Legislative Decree No 279/2004 was superseded by Statute No. 5 of 2005 with minor changes. ${ }^{203}$ Italian Parliament enacted a Coexistence Act on January 28, 2005. Originally, the cultivation of GM crops was prohibited in Italy. This prohibition was removed when the coexistence law of 2005 came into force. The coexistence law sets out a legal framework in which the 20 Italian regions would develop their own implementing regulations. The Italian coexistence law provides for, in compliance with EU Commission Recommendation 2003/556, the possibility of forming "homogeneous" regions (e.g., "GM-free" zones). Neither the Italian nor EU legislation defines what "homogenous area" means. If a broad interpretation is applied to this concept, it could eventually lead to an entire region being declared GM-free. The EU Commission has already expressed that they do not want this situation to occur. The precautionary principle is most commonly cited as justification for creating large GMfree regions. ${ }^{204}$

Currently, a commission under the coordination of the Ministry of Agriculture is creating general guidelines on which individual regions will be expected to base their detailed coexistence plans. In addition, every farmer who grows GM crops must create a farm-level coexistence plan and document all coexistence measures. The regions are to support voluntary agreements between neighbors. ${ }^{205}$ The coexistence law also states, "If neigh- bouring farmers suffer losses because of a failure to respect the co-existence rules, they are entitled to compensation. This must be paid by the person who caused the loss by contravening the coexistence rules." 206 The Italian Conference of Regions and Autonomous Provinces has prepared a guideline for regional coexistence laws. At the moment it has no juridical effect, but it is a strong political agreement. ${ }^{207}$

In March 2006, the Constitutional Court of Italy declared that Italy's Framework Law on Coexistence was unconstitutional. ${ }^{208}$ This issue was brought before the Constitutional Court by the Region Marche (one of the regions) and sought to declare the 2005 coexistence law as unconstitutional. According to the view of the Court, only the regions are entitled to regulate coexistence. The Constitutional Court affirmed the constitutional validity of Articles 1 and 2 of the 2005 coexistence law. Articles 1 and 2 relate to the freedom of consumers to choose between genetically modified and conventional products, and places limitations on cultivation to maintain separate production chains for conventional and organic products. The rest of the law was found to be contrary to the constitutional rights of the regions to enact their own agricultural legislation. ${ }^{209}$ This has resulted in large-scale confusion as to which of the rules already enacted will remain in force. ${ }^{210}$ For now, all

${ }^{199}$ Case C-236/01, Monsanto Agricoltura Italia SpA v. Prezidenza del Consiglio dei Ministri, [2003] ECR I-8105.

${ }^{200} I d$. at para 114 .

${ }^{201} 2003$ Commission Recommendation, supra note 4.

${ }^{202}$ Law Decree No. 279 of 22 November 2004: Concerning Control Measures in Order to Ensure the Co-existence of Genetically Modified, Conventional and Organic Crops.

${ }^{203}$ Law No. 5 of 28 January 2005: Conversion into Law, with Modification, of Law Decree No. 279 of 22 November 2004, and Bodiguel et al., supra note 23, at 176.

${ }^{204}$ Cantley, supra note 40 at 78 .

${ }^{205}$ GMO Safety: Genetic Engineering, Plants, Environment, National Coexistence Rules: Italy, GMO SAFETY, http:// www.gmo-safety.eu/coexistence/417.italy.html.

${ }^{206}$ Covino, D. (2016), GMOs and the issue of coexistence in Italy, Nutrition \& Food Science, Vol. 46 No. 5, pp. 659-671. https://doi.org/10.1108/NFS-11-2015-0147

${ }^{207}$ Italy, GMO-FREE EUROPE, http://www.gmo-free-regions .org/gmo-free-regions/italy.html (visited Dec. 12, 2011).

208 Judgment 116/2006 (Gazetta Ufficiale, Mar. 22, 2006). ${ }^{209}$ Id.

${ }^{210}$ Bodiguel et al., supra note 23 , at 178; National Coexistence Rules, supra note 206. 
regions have a de facto moratorium on the cultivation of GM crops. ${ }^{211}$

Earlier, in April 2005, when the Central government challenged regional measures like the declaration of GM-free regions before the Constitutional Court, Region Marche, as defendant, sought to uphold regional measures. In this case, ${ }^{212}$ which was the first decision on the GM issue, the Constitutional Court supported regional measures and said the regional measures were confined to the agriculture sector and did not relate to trade in GMOs.

In Italy, the Ministry of Agriculture is the main executing authority. The Ministry of Agriculture controls registration of seed varieties with the National Register and also sets policy when establishing the tolerance level for adventitious presence (AP) of GM seeds in conventional lots. Article 1 of the Legislative Decree of April 24, 2001 formally implements the EU Directive 98/95. It states that seed planting must be authorized by the Ministry of Agriculture, thereby ensuring the all appropriate measures are taken to prevent GM seeds from coming into contact with conventional seeds. ${ }^{213}$ The Ministry of Health is the Competent National Authority with respect to contained use of GMOs. The Decree (Italian Decree No. 224) transferred the leadership responsibility from the Ministry of Health to the Ministry of Environment. The same decree gave several ministries, including Health, Labour, Agriculture, Production Activities, and Education, a role in the authorization of new biotech events. Also the Inter-ministerial Evaluation Committee, composed of representatives from different ministries, was created under the Ministry of Environment. The general function of the several ministries is advisory. The decree gives autonomous competence to the Ministry of Environment, and to other ministries, like Health and Agriculture, to use the safeguard clause because it falls under their jurisdiction. ${ }^{214}$ These ministries can,

with an emergency act, temporarily limit or prohibit the release onto the market, the use or sale of a GMO, as such or contained in a product, if, after the date of authorisation, based on new information regarding the assessment of environmental risks, or following a new evaluation of the existing information, based on new or supplementary scientific knowledge, they have reasonable grounds to believe that such GMO can represent a risk for human or animal heath, or the environment. ${ }^{215}$

The European Commission passed nonbinding guidelines on coexistence in 2003 and subsequently passed new coexistence guidelines on July 13, $2010 .^{216}$ The guidelines open the possibility for member states to pronounce much more stringent rules for the cultivation of genetically modified plants. Therefore, there are vast differences in the level and form of the implementation of coexistence legislation across the members of the union. ${ }^{217}$ The Italian Ministry of Agriculture has always maintained a zero tolerance policy for contamination of conventional crops by GM crops. However, zero tolerance is actually $0.049 \%$, which is the minimum detectable value. ${ }^{218}$ The Italian biotech industry takes the position that the lack of any EU regulation concerning adventitious presence does not justify the zero tolerance policy of the government, ${ }^{219}$ despite negotiations to progress a standard approach. ${ }^{220}$

\section{CONCLUSION}

For the first time, Europe is able to develop biotechnological law and policy, but many countries are still in a dilemma. European biotechnology law has allowed patenting and commercialization of GMOs, but at the same time, it has given high priority to the safety of human and animal health and environment as well as public perception. All GMO crops, plants, or products need to go through scientific risk assessment before commercialization or release into the environment. All GMOs products are subject to labelling and traceability as well.

Many EU member states now have coexistence laws. EU member countries are free to offer its citizens the freedom to choose between genetically modified crops, conventional crops, and organic crops. They aim to reduce cross-contamination of GMOs by providing binding measures and also

${ }^{211}$ GMO Safety: Genetic Engineering, Plants, Environment, Coexistence in the Countries of the EU: A European Patchwork, GMO SAFETY (Feb. 22, 2010), https://web.archive .org/web/20151122001141/http://www.gmo-safety.eu/ coexistence/449.european-patchwork.html

${ }^{212}$ Judgment 150/2005 (Gazetta Ufficiale, Apr. 20, 2005).

${ }^{213}$ Cantley, supra note 40 , at 77.

${ }^{214}$ Id. at 78 .

${ }^{215} \mathrm{Id}$.

${ }^{216} 2010$ Coexistence Recommendation, supra note 5.

${ }^{217}$ Italy, supra note 208.

${ }^{218}$ Cantley, supra note 40, at 77.

${ }^{219} \mathrm{Id}$.

${ }^{220}$ See also M. Perry and R. Karky, Agriculture Under Threat-A Crisis Of Confidence? The Solution: Redefine Adventitious Presence Maximum Levels from Zero to Zero++, 11(1) CANAdian J. L. \& TeCh. 25-47 (2013). 
offer compensation in case of economic loss caused by the cross-contamination.

The EU has adopted the Precautionary Principle in its biotechnology law and accordingly, if GMO products are considered potentially harmful to health or the environment, EU member states are free to invoke the safeguard provision and ban GMO products temporarily. Also, EU member states, including regional authorities, are free to declare GMO-free zones if coexistence measures are not working effectively.

Furthermore, the EU consumers and NGOs are already hostile to GMOs. Only scientific societies are worried and concerned that Europe has not been taking advantage of the benefits of biotechnological advancement. It is also argued that GMO farming bears higher costs in Europe. Many biotech companies are not interested in GMO farming in Europe because of high costs and strict regulations.

The EU has always adopted a policy of harmonizing its laws and policy in other fields whereas, with respect to GMOs, it has adopted a policy of disharmonization. The EU has authorized its member states to formulate coexistence measures according to their needs and situations. Practically, different EU member states have different coexistence measures. GMO crops or plants are virtually banned in many regions of the EU.

Serious concerns and questions have been raised about whether Europe is falling behind other countries in not taking the advantage of the benefits of biotechnology, or whether its actions are indeed protecting their agricultural sectors from the monopoly of big biotechnology companies, or even protecting European public health and environment. The bulk of the science to date points in the safety and efficacy of biotech crops, although there are still ongoing concerns around these key issues. 